\title{
9. Sınıf Öğrencilerinin Kütüphanelerde Teknoloji Kullanımı Ve Okuma Alışkanlıkları: Gaziantep İli Şahinbey İlçesi Örneği
}

\section{Technology Use in Libraries and the Reading Habits of Ninth Grade Students: Example of the Sahinbey District of Gaziantep}

\author{
Ozan Kirtay $^{1}$ (D)
}

'Zeliha Ziylan Kız Anadolu Lisesi, Gaziantep, Türkiye

ORCID: O.K. 0000-0002-9067-1275

Sorumlu yazar/Corresponding author: Ozan Kirtay (Dr.),

Zeliha Ziylan Kız Anadolu Lisesi, Gaziantep, Türkiye

E-posta: ozankirtay@hotmail.com

Bașvuru/Submitted: 04.11.2020

Revizyon Talebi/Revision Requested: 16.11.2020 Son Revizyon/Last Revision Received: 28.11.2020 Kabul/Accepted: 02.12.2020

Online Yayın/Published Online: 31.12 .2020

Atıf/Citation: Kırtay, O. (2020). Ortaöğretim 9. Sınıf öğrencilerinin teknoloji-kütüphane kullanımı ve okuma alışkanlığı üzerine bir araştırma: gaziantep ili şahinbey ilçesi örneği. Bilgi ve Belge Araștırmaları Dergisi, 14, 105-133. http://doi.org/10.26650/bba.2020.14.04
ÖZ

Teknolojinin kullanım biçimine göre bireyler üzerinde olumlu ve olumsuz etkileri bulunmaktadır. Teknolojik öğelerin eğlence işlevinin bilinçsiz ve fazla kullanımı, bireylerin kütüphane kullanımlarına ve okuma alıskanlıklarına yeterince zaman ayıramamalarına yol açabilmektedir. Bu makalede Gaziantep ilinin Şahinbey ilçesinde öğrenim gören ortaöğretim 9. sınıf öğrencilerinin teknoloji bağımlılığı ve okuma alışkanlıkları arasındaki ilişki incelenmiştir. Bu amaç doğrultusunda araştırmanın yöntemi yordayıcı korelasyonel araştırma olarak belirlenmiş̧tir. Çalışmada 2019-2020 eğitim-öğretim yılının bahar döneminde 1075 öğrenciye iki ölçek ve bir anket formu uygulanmış ve sonuçlar geçerli olan 934 form üzerinden SPSS 22.0 ve Mplus 8.0 paket programları ile analiz edilmiştir. Araştırma sonucunda teknoloji bağımlılığı ve okuma alışkanlığı arasında negatif yönlü bir ilişkinin olduğu ve teknoloji bağımlılığının okuma alışkanlığı üzerinde yüzde 5 oranında bir etkisinin olduğu görülmüştür. Çalışmada kız ögrencilerin erkek öğrencilere göre daha fazla okuma alışkanlığına sahip olduğu ve interneti daha fazla eğitsel amaçlı kullandıkları anlaşılmıştır. Erkek öğrencilerin ise çevrimiçi oyunlara kız öğrencilere göre daha fazla zaman ayırdıkları görülmüștür. Ayrıca araştırmada teknoloji kullanımı açısından kız ve erkek öğrenciler arasında anlamlı bir fark olmadığı tespit edilmiştir. Anahtar kelimeler: Okuma alışkanlığı, teknoloji, lise öğrencileri, kütüphane, kitap

\section{ABSTRACT}

Technology has positive and negative effects on individuals depending on how it is used. The unconscious and excessive use of technological items for entertainment may cause individuals to sacrifice time they might otherwise spend in the library reading. In this article, the relationship between technology addiction and the reading habits of ninth-grade students studying in the Şahinbey district of Gaziantep province was examined. For this purpose, research method was determined as the predictive correlational research. In the study, two scales and a questionnaire were applied to 1,075 students in the spring semester of the 2019-2020 academic year, and the results were analyzed with the SPSS 22.0 and Mplus 8.0 package programs with 934 valid forms. The results indicate that there is a negative relationship between technology addiction and reading habits, and technology addiction has a $5 \%$ effect on reading habits. The findings also suggest that female students have stronger reading habits than male students, and they use the Internet more often for educational purposes. Conversely, male students spend more time on online games than female students. Moreover, we found no significant difference between male and female students in terms of technology use.

Keywords: Reading habits, technology, high school students, library, book 


\section{EXTENDED ABSTRACT}

Technological elements have both positive and negative effects on individuals according to their usage patterns. The unconscious and excessive use of technology for entertainment can cause individuals to sacrifice the time they might otherwise spend in the library reading. In this article, the relationship between technology addiction and reading habits is emphasized, considering that technology addiction, which may occur as a result of unconscious use of technological elements, directly affects reading habits. The aims of the study include determining how long students spend on the computer/Internet, whether they use the Internet and social media to obtain information, whether the presence of technological elements influences their reading habits and the extent to which technologies such as digital publications and e-book readers feature characteristics that can improve people's lives. For the development of an information-based society, it is also important that individuals have a habit of reading, know how to access information from using technology, and have a habit of using libraries. Therefore, this study also focuses on students' library usage habits. In this article, we examined ninthgrade students studying in the Şahinbey District of Gaziantep Province in Turkey. In the study, we evaluated the extent to which students use school and public libraries, why they use them, and their expectations from school or public libraries, as well as students' technology use in libraries and their reading habits. In the research, two scales and a questionnaire were applied to 1,075 students in the spring semester of the 2019-2020 academic year, and the results were analyzed with the SPSS 22.0 and Mplus 8.0 package programs with 934 valid forms. The results highlight a negative relationship between technology addiction and reading habits, and technology addiction has a 5\% effect on reading habits. Furthermore, female students have stronger reading habits than male students and use the Internet more often for educational purposes, and male students spent more time on online games than female students. Moreover, no significant difference was found between male and female students in terms of technology use. The importance of teaching information literacy as a course to secondary school students to reduce technology addiction and to enable young people to use the Internet consciously is one of the goals of this study. In this study, the participants mostly preferred school libraries (69\%), followed by public libraries $(53.7 \%)$. The necessity of teachers and administrators informing students to increase their library usage habits and library membership also became apparent through this study. Examining the expectations of students from school librariesplentiful electronic broadcast access options (18\%), digital infrastructure and resources (15\%), and computers with Internet access (12\%) - underscores the importance of advancing the enriched libraries project developed in Turkey. When the library usage habits of students are examined, the fact that $37 \%$ say that they never go to libraries but actually go several times a year indicates that students make little use of the opportunities at libraries. Therefore, the importance of experts working in the field of information and document management to transform libraries from the classical library and turning them into activity-oriented attraction 
centers with intense technological possibilities is notable. Considering students' views on reading books, the low rate of those who answered "none" (11\%) to the option "How long do you read books a day on average?" suggests that students have regular book-reading habits. Nevertheless, the reason for the small amount of time they spend reading each day is related to the excessive time they spend using technology. According to our study, $53 \%$ of students spend 3 hours or more a day on the Internet, whereas the rate of students who read 3 hours or more a day is $9 \%$. The fact that students spend a great deal of time on computers and the Internet is also highlighted through the answers to the following question: "What do you do most in your free time?" Among the respondents, 73\% chose "I spend time on the computer/ internet." In contrast, only 53.5\% reported reading books, magazines, newspapers, and so forth. The results of this study indicate that the rate of students using the Internet and social media to obtain information was high, but due to high rates of use of entertainment functions, which are among the available options, it was determined that the participants could not use the Internet and social media at sufficient levels to obtain information. Therefore, conscious Internet use education should be provided to students to address this issue. 


\section{GíRIŞ}

Bilgi tarihi dönemlere göre incelendiğinde dört önemli dönüm noktası olduğu anlaşılmaktadır. Bu dönüm noktaları yazının icadı, matbaanın bulunuşu, radyo-televizyon gibi kitle iletişim araçlarının keşfi ve internetin icadı ile birlikte bilginin dijital ortama aktarıldı̆̆ 1 dijital dönemdir. İnternetin bulunuşuyla birlikte internet üzerinden erişilen güvenilir kaynaklı raporlar, belgeler vb. ile bireyler bilgi dünyalarını genişletebilirken, internetin olumsuz etkileri ile de karşılaşabilmektedir. Teknolojik yeniliklere karşı öz disiplinli olmayan insanların; teknolojik öğelerin eğlence işlevine fazla vakit harcamalarından dolayı okuma alışkanlıkları olumsuz yönde etkilenebilmektedir.

Çağımızda bilgi toplumu olabilmek için bireylerin okuma alışkanlığına sahip olması, kütüphane kullanım alışkanlıklarının olması ve bilgiye dijital ortamdan erişebilmenin yollarını biliyor olmaları önemli bir husustur. İnsanlık tarihi açısından incelendiğinde ise bu hususun geçmiş dönemler ile çağımız arasında paralellik göstermekte olduğu anlaşılmaktadır. İnsanlık tarihinin hangi döneminde olursa olsun bilgiye hızlı erişen, edindiği bilgileri teoriden uygulama düzeyine geçirerek bu bilgilerin kullanışlı hale gelmesini sağlayan, bir sonraki nesle bilginin aktarılmasında doğru yöntemleri uygulayan toplumlar, sosyal, siyasal ve toplumsal gelişmişlik düzeyi açısından diğer toplumlara göre daha ileri düzeyde olmuşlardır.

Toplumların gelişmişlik düzeyleri o toplumda yaşayan genç bireylere verilen eğitim ve öğretim ile doğru orantılıdır. Okuma alışkanlığı olan ve bilgiye erişebilme yollarını bilen öğrenciler, eğitim-öğretim hayatlarını bitirdikleri zaman içinde bulunduğu toplumun kalkınmasına yönelik adımlar atmaktadır. Günümüzde ise yaşadı̆̆ımız dijital çağda, bilgiye internet ve sosyal medya ile de ulaşılabilindiği için, öğrencilerin bilgiye dijital ortamdan erişebilmesi de önem kazanmaktadır.

Bu makalede; Zeliha Ziylan Kız Anadolu Lisesinde (Şahinbey, Gaziantep) öğrenim gören ortaöğretim 9. sınıf öğrencileri özelinde teknoloji bağımlılığı ve okuma alışkanlığı arasındaki ilişki incelenmiştir. Ayrıca teknolojinin okuma alışkanlığını etkilemesi açısından olumlu yönleri ve olumsuz etkileri hakkında bilgiler verilmiştir. Ortaöğretim 9. sınıf öğrencilerinin internette, sosyal medyada ve çevrimiçi oyunlarda ne kadar süre harcadıkları, internet ve sosyal medyanın bilgi edinme işlevinden ne düzeyde faydalandıkları, kitap okumaya ne kadar süre harcadıkları, e-kitap okuyucu cihazları kullanım oranları incelenmiştir. Ayrıca ortaöğretim 9. sınıf öğrencilerinin okul ve halk kütüphanelerini hangi sıklıkla ve ne amaçla kullandıkları, kütüphane üyelikleri, en son ne zaman bir kitap bitirdikleri, hangi tür kitaplar okudukları, kütüphanelerden beklentileri, kütüphanecilerden yardım alma alışkanlıklarının olup olmadığ gibi soruların cevapları araştırmanın hedeflerini oluşturmuştur. Araştırmada yapılan çalışmayı desteklemek amacıyla Gaziantep ilinin Şahinbey ilçesinde bulunan farklı lise türlerinde okuyan ortaöğretim 9. Sınıf öğrencilerine konuyla ilgili bir anket ve iki ölçek uygulanmıştır. 
Araştırmada kitap okumaya yönelik tutum bağımlı değişken, teknoloji bağımlılığı ise bağımsız değişken olarak ele alınmıştır. Bu nedenle araştırmanın yöntemi değişkenler arası ilişkilerin incelendiği, ‘yordayıc1 korelasyonel model' deseni olarak belirlenmiştir.

\section{Okuma ve Okuma Alışkanlığı}

Bilgi kavramı ile ilgili farklı bilim dallarından birçok araştırmacı çeşitli çalışmalarda bulunmuştur. Bu kavramın hem bireylerin hem de toplumların gelişmesinde kilit rol oynaması, bilgi kavramıyla ilgili yapılan araştırmaların temel nedenlerinden biridir.

Bilgi, insanlığın ilk dönemlerinden itibaren, toplumların temel ihtiyaçlarından birisidir. Bilginin zamanla üretiminde büyük bir artış göstermesiyle birlikte insanlık açısından bilgi, büyük bir güç unsuru haline gelmiştir. Bilginin bireylerin gelişmesini ve doğaya hâkim olmasını sağlamasıyla birlikte, insanlar bilgiye sürekli ihtiyaç duymaya başlamış ve bu doğrultuda bilgi arama davranışı göstermeye başlamıştır. (Yılmaz, Köse, Korkut, 2009, s. 24).

Bilgiye erişebilmenin en temel yolu ise okuma vasıtasıyla gerçekleşmektedir. Okumak sayesinde bireyler istedikleri alanda istedikleri konuda bilgi sahibi olabilmektedir. Bilgi sahibi bireylerin, farkındalık güçlerinin yüksek ve benlik duygularının güçlü olması, bireysel ve toplumsal açıdan yaşamlarını kolaylaştırabilmesi yönüyle çok önemlidir. Bu nedenle bireylerin kendilerini yetiştirebilmesi ve geliştirebilmesi için çok okuyup, çok öğrenmesi insan yaşamı açısından mühim bir husustur.

İnsanı diğer varlıklardan ayıran temel özelliklerden biri ise geçmiş kuşağın bilgi birikimini elde ederek, bu bilgi birikimine yeni öğeler ekleyerek bu birikimi bir sonraki kuşağa aktarmasıdır. Yazı icat edilmeden önce bu durum sözel yollarla gerçekleştirilmiştir. Yazının icat edilmesinden itibaren ise bilginin elde edilmesi, paylaşılması ve aktarılması süreci dilsel ifadelere kıyasla çok daha hızlanmıştır. Bu hız toplumların bilgi birikiminin hızlı bir biçimde artmasına yol açmıştır. Bu durum ise bilgiye erişimin en önemli aracı olan okumanın öneminin bireyler tarafından anlaşılmasını sağlamıştır. Günümüzde okumak bireylerin vazgeçilmez edimleri arasında yer almaktadır. (Konan, 2013, s. 32).

Okuma bireyin içinde bulunduğu dünyayı tanımasını sağlayan, yaşamını zenginleştiren; kişisel ve toplumsal kimliğini kazanmasında etkili olan bir dil becerisidir ve öğrenildikten sonra yaşamın sonuna kadar bireyin gereksinimi olan temel ihtiyaçlarından biridir. (Şahin, 2010, s. 1450).

Okumanın işlevleri arasında bireylerin bilgi birikimini genişletmesinin yanı sıra aynı zamanda bireylerin davranış biçimlerini değiştirmesi de bulunmaktadır. 
Okumak bir yandan bireylerin düşünce dünyalarını geliştirirken diğer taraftan eleştirel ve analitik düşünebilme becerilerini de ilerletir. Okuyan bireyler ile okumayan bireyler arasında davranış biçimleri arasında farklılıklar vardır. İnsanlar yaşamları boyunca okuyarak kendilerini geliştirebilmek için gayret göstermelidir. (Ungan, 2008, s. 229).

Bilgiye ulaşabilmenin en temel yolu okumaktır" (Sarı, 2016, s. 7). "Okuma konusunda çeşitli tanımlar bulunmaktadır. Bu konu hakkında kullanılan en geniş tanım ise hissedilenlerin anlamlandırılmasıdır" (Mantıoğlu, 2017, s. 21). "Eğitimde başarıya ulaşabilmenin yolu okumak vasıtasıyla gerçekleşir. Okuma, eğitimde ve hayatın bütün alanlarında potansiyel bir güçtür. Okuma alışkanlığına sahip olmak yalnızlığa karşı savunma becerisidir. Okuma edimi sayesinde geçmiş ve gelecek bugüne taşınmaktadır. (Fatiloro, Adesola, Hameed, Adewumi, 2017, s. 106).

Okuma alışkanlığı, bireylerin hangi sıklıkta okuduğu, okumaya ne kadar süre ayırdığı, ne zaman ve ne okuduğunu ifade eder. Okuma; kitapları, basılı ve elektronik yayınları içeren bir alışkanlıktır. Materyallerin okuma alışkanlığına etkisi birbirinden farklıdır. (Rosli, Razali, Zamil, Noor, Baharuddin, 2017, s. 791).

Bireylerin yaşam boyu öğrenme becerisine sahip olabilmeleri için hayatlarının geçmiş dönemlerine göre sürekli olarak bilgi birikimlerini artırmaları gerekmektedir. Kişilerin hangi yaşta olursa olsun, bilgi seviyelerini ilerletmeleri, bilgilerini bir sonraki kuşağa aktarabilmeleri, toplumun gelişmesi açısından mühim bir olgudur. Bu açıdan okuma alışkanlığına sahip olmak öğrenmenin yaşam boyu sürdürülebilmesi ve bilgi birikiminin sürekli artış halinde olması için temel gereksinimdir denilebilir.

Okuma alışkanlığ 1 ve okur tipleri arasında farklı zamanlarda farklı araştırmacılar tarafından çeşitli araştırmalar yapılmıştır. Bu konuda çalışmalar yapan araştırmacılardan biri olan Richard Bamberger okuma malzemeleri ve okur tipleri arasındaki ilişkiyi inceleyerek dört farklı okur tipi belirlemiştir. Bu okur tipleri aşağıdaki gibidir:

a- Romantik tip: Bu okur tipi çoğunlukla 9-11 yaş aralığındaki çocuklarda görülür. $\mathrm{Bu}$ bireyler büyüleyici eserleri daha sık okurlar. Bu eserlerin hikâye olması genellikle ön plana çıkmaktadır. Eserlerin edebi yönünün bulunmaması ise fark edilen özelliklerindendir.

b- Gerçekçi tip: Bu okur tipi fantastik öğeleri içeren, hayal ürünü olan, içerisinde masalımsı figürleri barındıran eserleri sevmezler. Gerçekçi tip okurları çoğunlukla yaşamın içerisinde yer alan (realist) eserleri tercih ederler.

c- Entelektüel tip: Bilgi verici eserleri severler. Eserlerin içerisinde determinist (neden sonuç ilişkisi) öğelerin bulunması bu okur tipi için önemlidir. Eserlerde 
açıklayıcılık faktörü aranan unsurlardan biridir. Erken yaşta öğrenmek isterler. Entelektüel tip okurları edebi eserleri pek tercih etmemektedir, hikâye okuyacak olsalar bile hikâyelerin kendilerine uygulamada getireceği yararları göz önünde bulundururlar.

d- Estetik tip: Genellikle şiirlerden hoşlanırlar. Estetik tip okurları şiirlerin içerisinde bulunan ahenk ve uyumdan etkilenir. Her yaş grubunda görülebilir. Bu okur tipi kitapların içerisinde hoşlarına giden bölümleri not almayı severler. (Bamberger, 1990, s. 19).

Amerikan Kütüphane Derneği (ALA) bireylerin okudukları kitap sayılarına göre hangi okur tipinde olduklarına yönelik çalışmalarda bulunmuştur. Elde ettikleri sonuca göre; "Bir yılda bir-beş arasında kitap okuyanlar az okuyan okur tipi, yılda altı-yirmi arasında kitap okuyanlar orta düzeyde okuyan okur tipi ve yılda yirminin üzerinde kitap okuyanlar ise çok okuyan okur tipi olarak nitelendirilmiştir” (Aktaran Durualp ve Durualp, Çiçekoğlu, 2013, s. 116).

\section{Teknoloji ve Okuma Alışkanlığı}

Toplumsal dönemleri incelediğimizde, bilgisayar ve internet teknolojilerinin ortaya çıkmasıyla, sanayi toplumundan bilgi toplumuna geçildiği görülmektedir. Bilgi toplumunda bireyler bilişim teknolojileri vasıtasıyla bilgiye hızlı ve kolay bir biçimde erişebilmektedir. $\mathrm{Bu}$ durum, bilişim teknolojilerinin günümüzde yaşamımız için ne kadar önemli bir kavram olduğunu göstermektedir.

Bilişim teknolojileri bireysel ve toplumsal iletişimi kolaylaştırmak ve iş yaşamını daha uygun koşullarda sürdürmek amacıyla günümüzde insanların yararlandığı önemli araçların başında gelmektedir. Yaygınlaşmaya başladığı dönemlerde yazı, bilgi ve fikir üretimini, kullanımını, paylaşımını ve bilginin kalıcı olmasını sağlamak gibi amaçlarla hizmet veren bilişim teknolojileri, günümüzde yayıncılık, kütüphanecilik ve eğitim gibi bilim ve kültür alanlarında pek çok sürecin dijitalleşmesine ön ayak olmaktadır. Günümüzde yazın ürünlerinin ve arşiv belgelerinin büyük oranda dijitalleştiği bir dönem yaşanmaktadır. Doğal olarak da dünya okuma eyleminin dijital ortamlar üzerinde sürdürüleceği bir döneme doğru hızla ilerlemektedir. (Odabaş ve Odabaş, Binici, 2019, s. 92-93).

Günümüzde bireyler okuma alışkanlığını basılı yayınların elektronik ortamlara aktarılabilmesi imkânı ile e-kitap okuyucu, tablet, bilgisayar gibi teknolojik ürünler vasıtasıyla gerçekleştirebilmektedir. Bir kitabın veya bir derginin vb. ister basılı ortamdan olsun ister elektronik ortamdan olsun okunması, her iki durumda da okuma fiilinin gerçekleştirilmiş olmasını sağlar. Çağımızda teknolojik gelişmelerin yol açtığı sonuçlar ile e-kitap okuyucular sayesinde birçok kitabı yanımızda taşıyabilmekteyiz. Basılı materyallerin elektronik materyallere göre avantajlarının ve dezavantajlarının olmasının yanı 
sıra günümüzde koşullara göre her iki materyalin avantajlarından faydalanabilmek, iyi bir okur olabilmek için önemli bir husus teşkil etmektedir. Elektronik materyallerin basılı materyallere göre avantajlarını ve dezavantajlarını 'Baldini’ aşağıdaki gibi belirtmiştir:

Basılı Materyaller: Okuma yeteneği gerektirmektedir, genellikle bireyseldir, yavaş kullanılır, azar azar kullanılır, tekrar okunabilip denetlenebilir, üretimi ucuzdur, tüketici için pahalıdır, farklı perspektifteki gruplar için yapılmıştır.

Elektronik Materyaller: Herhangi bir eğitim ihtiyacı gerektirmemektedir, çabuk yayılır, büyük boyutta kullanılır, genellikle bireysel değil toplumsal temellidir, genellikle ikinci gözleme ihtiyaç duymaz, üretimi pahalıdır, tüketici için ucuzdur, çoğunluğun kullanımı için yapılmıştır. (Baldini, 2000, s. 92-93).

Gerek basılı materyallerde gerekse elektronik materyallerde bilginin saklanması ve güvenliği önemli bir husustur.

Sözlü kültür içerisinde bilgiyi kaybetme kaygısı, bilgi sahibi insanları kaybetme ve bu insanların bilişsel yetilerinin yok olmasıyla ilişkilidir. Yazılı kültürde ise kitapların ortadan kalkması veya yakılmasıyla ilgilidir. Tarihin bazı dönemlerinde gördüğümüz kütüphanelerin yakılması bu durumun bir göstergesidir. Teknoloji çağında ise bilgisayar sistemlerine virüs bulaşması, geri alınamayan işlemlerle karşılaşılması, bilgiyi kaybetme korkusunu oluşturmaktadır. Bu duruma çözüm olarak ağ sistemlerinde sanal bellekler geliştirilmiştir. Ancak bu bellekler vasıtası ile de sorunlar yaşanmayacağının kesinliği yoktur. Sonuç olarak bilgi dijital verilerdir ve ortadan kalkma tehlikesiyle karşı karşıyadır. (Küçükkalkan, Öztürk, 2018, s. 35).

Bu da elektronik yayınların -basılı yayınlara göre- dezavantajlarından birisidir.

"Elektronik yayınların basılı yayınlara göre avantajlarından biri ise elektronik yayınlardaki hataları düzeltebilme imkânıdır. Matbaada basımı gerçekleştirilen bir basılı yayındaki hataları düzeltmenin herhangi bir yolu yoktur. Ancak internet üzerinden sunulan yayınlarda yapılan hatalara anında müdahale etme olanağı bulunmaktadır” (Sivrikaya, 2009, s. 37).

Günümüzde hem basılı yayınların hem de elektronik yayınların uygun koşullar altında kullanılması bireylerin okuma alışkanlıklarını geliştirebilmeleri için gerekli bir husustur. Doğru koşullar içerisinde elektronik materyaller kullanarak okuma alışkanlığımızı geliştirebilmek teknolojinin bize sunduğu olumlu olanaklardan birisidir. Bu açıdan okuma alışkanlığı hususunda teknolojik öğelerin avantajlarını kullanabilmek bireylerin gelişimi açısından önem teşkil etmektedir.

En son geliştirilen elektronik cihazların birçoğu, geleneksel olarak sadece bir format için tasarlanmış bir dizi dijital olarak üretilmiş içeriğe erişebilir ve bunları depolayabilir düzeydedir. Örneğin, bir televizyon programı artık günümüzde bir 
tablette veya bir akıllı telefonda aynı bir televizyondaki gibi görüntülenebilir. Dijital içeriğin artmasıyla, teknolojik cihazlar bilgi kaynaklarının ve hizmetlerinin yakınsamasını mümkün kılmaktadır. Örneğin, bir tablet dijital olarak üretilen radyo ve televizyon programlarına, filmlere, derslere, kurslara, dijital depolara, gazetelere ve dergi içeriğine erişebilir. Bu mobil cihazların faydası açık olsa da, yeni, rakip teknolojilere ek olarak sürekli güncellenmeleri ve değiştirilmeleri, sürekli değişen bu cihazları barındırmak için bilgi kaynaklarını organize etmeye ve yaymaya çalışan kütüphaneler gibi kurumlar için zorluklar yaratmaktadır. (Rubin, 2017, s. 3).

Bu nedenle kütüphanelerde içeriklerini dijital ortama taşımaya başlamıştır. Günümüzde geleneksel kütüphaneciliğin yanı sıra dijital kütüphanecilik kavramı da ortaya çıkmıştır. Dijital kütüphanecilik ile birlikte okuyucular milyonlarca belgeye bilgisayarından çevrimiçi yollarla erişebilmekte ve bu belgelerdeki bilgileri kullanabilmektedir. Bu durum günümüzde teknolojinin kütüphaneler üzerindeki etkisine örnek olarak gösterilebilir.

\section{Kütüphaneler ve Okuma Alışkanlığı}

Kütüphanelerin okuma alışkanlığına olan etkisini anlayabilmek için öncelikle kütüphanelerin işlevlerinden bahsetmek gerekmektedir.

Bilgi çağıyla birlikte, bilgiye gereksinim duyan, ihtiyacı olan bilgileri en doğru ve güncel şekliyle en hızlı bir biçimde elde etmek isteyen insanlardan oluşan bir toplum biçimi ortaya çıkmıştır. Bilgi toplumu olarak isimlendirilen bu toplum biçimi; araştırabilen, sorgulayabilen, düşünebilen ve analiz edebilen kişilerden oluşmaktadır. Bilgi ihtiyacı, bu toplum biçiminin yaşamının bir gereksinimi olarak ortaya çıkmıştır. Toplumsal bilgi ihtiyacını en hızlı ve güvenilir bir şekilde karşılamak kütüphanelerin görevleri arasında bulunmaktadır. Bu nedenle kütüphaneler bireylerin bilgi kaynaklarına erişebilmesine imkân sağlayan kurumlardır. (Çetintaş, 2018, s. 265). İçinde bulunduğumuz enformasyon çağında bilgi ve iletişim teknolojileri toplumsal, ekonomik, siyasal, kültürel yapılarla entegre olmuştur. Bilgi ve iletişim teknolojilerinde yaşanan hızlı ilerlemeler, iletişim ortamlarının teknik olarak birbirlerine yakınlaşmalarını sağlamış, toplumların birbiriyle etkileşimini arttırarak bilginin küresel boyutta hızla yayılımını beraberinde getirmiştir. Bilginin yayılmasına yardımcı olan kurumların en başında olan bilgi merkezleri olan kütüphaneler, kurumların içinde barındırdığg eserler (basılı, elektronik vb.) ve arşivleriyle bilimin, sanatın, teknolojinin gelişmesine katkıda bulunan önemli kurumlardır. (Kuzucuoğlu ve Şeşen, 2020, s. 9).

Kütüphaneler içerisinde bulundurduğu zengin kitap ve kitap dişı materyaller dermeleriyle birlikte bireylerin araştırmaya yönelik istek ve motivasyonlarını arttırarak, bilgi dünyalarını 
geliştirmelerini sağlamaktadır. Kişiler, bilgi hazinelerini geliştirebilmenin en temel yolunun okumaktan geçtiğinin farkına vararak, kütüphane kullanım alışkanlığına sahip olmaktadır. Kütüphaneler kullanıcılarına kitap temin etmenin yanı sıra uygun koşullarda kitap okuyabilme ve ders çalışabilme imkânı tanıdığı için de kullanıcılar tarafından ayrıca tercih edilmektedir. Kitapların içerisinde, sessiz bir ortamda, aynı davranışı paylaşan bireylerle birlikte bulunulan ortam kitap okuma alışkanlığını olumlu açıdan etkilemektedir.

Öğrencilerin okuma alışkanlığına sahip olabilmesinde kütüphanecilerin aktif rolü bulunmaktadır. Kütüphanecilerin öğrencilerle iletişiminin güçlü olması ve öğrencilerin bilgiye erişim süreçlerinde onlara faydalı olabilmeleri, öğrencilerin kütüphaneleri daha çok sevmelerine yol açacaktır.

Çocukların okuma alışkanlığını kazanabilmesinde ailelerin ve eğitim kurumlarının etkisi büyüktür. Çocukları okumaya teşvik edecek ortamların oluşturulması bu alışkanlığın kazandırılmasında önemli bir husustur. Öğrencilerin eğitim-öğretim yaşamlarında elde ettikleri kazanımların ailesi ve çevresi tarafından da desteklenmesi okumanın önemini anlayabilmelerine yol açmaktadır. Aile ve çevre çocuğa okuma alışkanlığı kazanmasında olumlu bir tutum sergilerse çocuk da bu durumdan olumlu yönde etkilenir. Bireyin gelişiminin kriterlerinden biri okuma alışkanlığı ise, toplumun gelişmişlik göstergesi ise kütüphaneleri kullanmasıdır. Günümüzde toplumların refah seviyesi ile okuma alışkanlığı arasında doğrudan bir ilişki bulunmaktadır. (Aydoğdu, 2020, s. 201).

Kütüphanelerin bireylere okuma alışkanlığı kazandırabilmesinde kütüphanecilere de önemli görevler düşmektedir. Çağımızda, kütüphaneciler bilgi teknolojileri açısından kendilerini geliştirebilmiş ve kullanıcılarına bu açılardan destek olmalıdırlar.

Öğrencilerin okuma alışkanlığg kazanmasında halk kütüphaneleri ve okul kütüphanelerinin etkisi büyüktür. Öğrenciler eğitim-öğretim hayatlarına başladıkları andan itibaren bu iki kütüphane türü ile sık sık karşılaşmaktadır.

Halk kütüphaneleri herhangi bir maddi beklenti içerisine girmeden toplumun bütün kesimlerinden bireylerin bilgi ihtiyaçlarını yaşam boyu karşılama sorumluluğunu üstlenen kurumlardır. Bu kurumlar aynı zamanda kullanıcılara sunduğu hizmetlerle öğesi olduğu toplumun eğitim, sosyal, ekonomik ve kültürel gelişimine katkıda bulunmaktadır. Halk kütüphaneleri demokratik yaşamın öngördüğü kütüphane kurumlarından olup günümüzde yaşanan hızlı gelişmelerden dolayı kullanıcıların beklenti ve bilgi ihtiyaçlarının değişmesi nedeniyle bu ihtiyaçları karşılayabilmek amacını taşımaktadır. Bu amaç halk kütüphanelerinin temel hizmet süreçlerinin başında gelmektedir. (Işık, 2019, s. 65). 
Halk kütüphaneleri kişilerin sadece bilgi ihtiyaçlarının giderilmesine yardımcı olmanın yanı sıra aynı zamanda bireylere kitapları sevdirme ve okuma alışkanlığı kazandırma hususunda da etkilidirler. İçeriğinde zengin dermeleri bulunduran bu kütüphane türü kullanıcıların okumak istedikleri yayınlara ulaşması konusunda yardımda bulunurlar. Aynı zamanda bu kütüphane türü kullanıcıların uygun ortamda kitap okumalarına imkân sağlamaları sayesinde de bireylerin kitap okuma alışkanlığı kazanmaları hususunda önemli bir işlev yürütmektedir. Halk kütüphaneleri, öğrencilere uygun ders çalışma ortamı sunduğu için öğrenciler tarafından sıklıkla ziyaret edilmektedir. Halk kütüphaneleri özellikle eğitim-öğretim çağı içerisinde bulunan bireylerin bilginin işlevinin ve kitap okumanın önemini kavrayabilmelerine yardımcı olabilmesi açısından çok önemlidir.

Halk kütüphanesinde çalışan personellerin -genellikle doğrudan kullanıcılarla yüz yüze iletişim kurmasından dolayı- insan ilişkileri ve iletişim becerilerine sahip olması önemlidir. Bu açıdan personellerin kullanıcıya istediği kaynağı en doğru ve hızlı biçimde verebilecek donanımda olması gerekmektedir. Aynı zamanda çalışanların hizmetlerin geliştirilmesine açık ve araştırmacı yönlerinin bulunması ve güler yüzlü, sıcakkanlı, yardımsever olmaları da önemlidir. Alanında uzman olan kütüphaneciler kullanıcı ve kütüphane arasında sağlıklı ilişkilerin kurulması ve profesyonel hizmetlerin geliştirilmesinde vazgeçilmez bir öneme sahiptir. (Cengiz, 2019, s. 5).

Halk kütüphaneleri toplumun bütün kesimlerinden bireylere hitap ettiği için okuma alışkanlığının kazanılmasında ve bu alışkanlığın sürdürülebilmesinde çok önemli bir yere sahiptir. Henüz daha okula dahi başlamamış bir çocuk halk kütüphanelerinin çocuklara özgü bulunan bölümlerinde zengin kitaplıklar arasında psikolojik olarak bu durumdan olumlu bir şekilde etkilenerek okuma alışkanlığını içselleştirebilir. İsteklendirilen (heveslendirilen) bir çocuk eğitim hayatı sürdükçe istediği zaman halk kütüphanelerinin imkânlarından faydalanabilmeye devam eder. Okul hayatı bitse dahi yaşam boyu bu imkândan faydalanacağı için halk kütüphaneleri bireylerin okuma alışkanlığını sürdürebilmesinde bir köprü görevi görmektedir.

Öğrencilerin okuma alışkanlığı kazanmasında önemli olan diğer kütüphane türü ise okul kütüphaneleridir.

Okul kütüphaneleri eğitim-öğretim kurumları içerisinde yer alan, bu kurumların eğitim öğretim faaliyetlerini desteklemek amacıyla gereken bütün bilgi kaynaklarını sağlayan, düzenleyen ve etkin bir biçimde hizmete sunan bilgi merkezleridir. Öğrencilerin sorumlu vatandaş olarak yaşama hazırlanmasında önemli kurumlar olan okulların temel yardımcısı olan okul kütüphanelerinin önemi eğitim öğretim içerisinde tartışılmaz bir yere gelmiştir. (Yılmaz, 2015, s. 208). 
Öğrenciler ders dışı saatler haricinde hem merak ettiği konuları araştırabilmek, hem de ödevlerini yapabilmek için kaynaklara bakabilmek amacıyla okul kütüphanelerinden faydalanabilmektedir. Okul kütüphaneleri sayesinde öğrenciler uygun ders çalışma ortamları bulabildikleri gibi aynı zamanda istediği kitapları, dergileri seçerek de okuma alışkanlıklarını geliştirmektedir. Bu nedenle bu kütüphane türü de öğrencilerin en sık kullandığı kütüphane türleri arasında yer almaktadır.

\section{Araştırmanın Amacı ve Hipotez}

Araştırmada teknolojik öğelerin bilinçsiz kullanımı sonucunda ortaya çıkabilecek teknoloji bağımlılığının okuma alışkanlığına doğrudan etki edeceği düşünülerek teknoloji bağımlılığı ile okuma alışkanlığı arasındaki ilişki üzerinde durulmuştur. Öğrencilerin bilgisayarda/ internette ne kadar süre harcadıkları ve interneti, sosyal medyayı bilgi edinebilmek amaciyla kullanıp kullanmadıkları, teknolojik öğelerin varlığının okuma alışkanlıklarını etkileyip, etkilemediği; dijital yayınlar, e-kitap okuyucu gibi teknolojinin kişileri geliştirebilecek taraflarını ne ölçüde kullandıklarını anlayabilmek araştırmanın temel hedeflerindendir. Bilgi toplumu olabilmek için bireylerin okuma alışkanlığına sahip olması, teknolojik unsurlardan bilgiye erişebilmenin yollarını bilmesiyle birlikte kütüphane kullanım alışkanlığına sahip olması çok önemli bir husustur. Bu sebeple öğrencilerin kütüphane kullanım alışkanlıklarını incelemek de araştırmanın hedeflerindendir. Araştırmanın hipotezleri şu şekilde belirtilebilir: a) Teknoloji bağımlılığı ile okuma alışkanlığı arasında ilişki yoktur (negatif yönlü bir ilişki vardır), b) teknoloji bağımlılı̆ğ cinsiyete göre farklılaşmamaktadır (erkek öğrencilerin teknolojik bağımlılık düzeyi kız öğrencilere göre daha yüksektir), c) kitap okumaya yönelik tutum cinsiyete göre farklılaşmamaktadır (kız öğrencilerin kitap okumaya yönelik tutumları erkek öğrencilere göre daha yüksektir), d) öğrencilerin internet kullanım amaçları cinsiyete göre farklılaşmamaktadır / farklılaşmaktadır, e) öğrencilerin çevrimiçi oyun oynama süreleri cinsiyete göre farklılaşmamaktadır / farklılaşmaktadır.

\section{Araştırma Modeli ve Veri Toplama Araçları}

Araştırmada yordayıcı korelasyonel model temel alınmıştır. "Bu model biçimi değiş̧kenler arasındaki ilişkilerin ele alındığı ve bir değişkenden yola çıkılarak diğer değişkenlerin yordanmaya çalışıldığı araştırma modelidir” (Büyüköztürk vd. 2017). Araştırmanın bağımlı değişkenini kitap okumaya yönelik tutum oluştururken, bağımsız değişkeni ise teknoloji bağımlılığıdır. Araştırmada veri toplama işlemleri Güçlü (2015) tarafından geliştirilen Teknoloji Bağımlılığı Ölçeği, Gömleksiz (2004) tarafından geliştirilen Kitap Okuma Alışkanlığına İlişkin Tutum Ölçeği ve araştırmacı tarafından geliştirilen kişisel bilgi formu üzerinden gerçekleştirilmiştir. Ayrıca lise öğrencilerinin kitap okuma alışkanlıkları ve teknoloji kullanımlarına ilişkin soruların yer aldığ 1 anket formu araştırmacının kendi hazırladığı sorularla birlikte Aydın (2017), Davarcı (2013) ve Önal ve Alaca'nın (2015) çalışmalarından yola çıkılarak geliştirilen 
sorulardan oluşmaktadır. Anket formundaki sorular çoktan seçmeli, sıralamalı ve açık uçlu soru biçimlerinden oluşmaktadır. Soruların herhangi bir doğru ya da yanlış yanıtının olmadığı katılımcılara vurgulanmıştır. Veri toplama araçlarına ilişkin öncelikle 87 kişilik bir grup üzerinde ön güvenirlik analizleri yapılmıştır. Bu analizler sonucunda ölçme araçlarının kullanım durumuna karar verilmiştir. Uygulanan ön güvenirlik analizi sonucunda teknoloji bağımlılı̆̆ ölçeğinin ve kitap okumaya yönelik tutum ölçeğinin cronbach alfa iç tutarlık katsayısı ve madde toplam korelasyon katsayıları hesaplanmıştır. Elde edilen sonuçlara göre ölçeklerin genel itibariyle çalışmanın gerçekleştirilebilmesi için yeterli düzeyde olduğu görülerek veri toplama sürecine geçilmiştir.

\section{Verilerin Toplanması}

Araştırma ilk olarak etik kurul izninin alınmasıyla başlamıştır. Bu iznin ardından Milli Eğitim Bakanlığından gerekli olan izinler alınmıştır. Araştırmada elde edilen verilere covid-19 etkisi nedeniyle öğrencilere yüz yüze ulaşabilme imkânının olmamasından dolayı çevrimiçi bir form aracılığıyla erişilmiştir. Çevrimiçi ortamda oluşturulan form iki bağımsız araştırmacı tarafından incelenmiştir. Bu inceleme sonucunda formda ifade hataları ve yazım yanlışlarının olmadığı anlaşılmıştır. Sonraki süreçte beş öğrenciye pilot uygulama yapılmıştır. Pilot uygulama sonucunda olumlu geri dönütlerin alınmasıyla veri toplama süreci başlatılmıştır. Araştırmacının oluşturduğu Google Forms dosyası bir bağlantı (link) üzerinden öğrencilere iletilmiştir. Verilerin toplanması süreci hedeflenen minimum öğrenci sayısı olan 932 öğrencinin üstüne çıkılarak 1.075 öğrenci sayısı ile tamamlanmıştır. (Evrende bulunan 18.633 öğrencinin en az \%5'ine ulaşılması hedeflenmiştir.

\section{Verilerin Analizi}

Verilerin analizi Tabachnick ve Fidell'in (2015) çalışmalarından yola çıkılarak gerçekleştirilmiştir. Öncelikle veri seti kontrol edilmiştir. Ardından hatalı veriler veri setinden çıkarılmıştır. Hatalı verileri anlayabilmek için iki ölçeğin içerisine de kontrol maddeleri yerleştirilmiştir. Araştırmaya katılan katılımcıların sorulara sağlıklı bir biçimde cevap verip vermediklerini anlayabilmek için iki tane kontrol maddesi kullanılmıştır. Teknoloji bağımlılı̆̆ ölçeğinin 25 ve 26. maddeleri arasına bu maddenin cevabını kesinlikle katılmıyorum seçeneğini işaretleyiniz ve kitap okumaya yönelik tutum ölçeğinin 25 ve 26. maddeleri arasına bu maddenin cevabını kesinlikle katılıyorum diye işaretleyiniz ifadelerine yer verilmiştir. Maddelere hatalı cevap veren 136 katılımcı veri setinden çıkarılmıştır. Ardından veri setindeki tek boyutlu uç değerler ele alınmıştır. Bu konuda ölçeklerin alt boyutlarına verilen toplam puanların, standart değerlerin -3 ve +3 değer aralığı dışında olanlar (Büyüköztürk, 2018) veri setinden çıkarılmıştır. $\mathrm{Bu}$ nedenle beş katılımcının daha veri setinden çıkartılmasıyla 934 katılımcı üzerinden veri analizine geçilmiştir. 
Veri seti analize hazır hale getirildikten sonra analiz aşamasına geçilmiştir. Araştırma kapsamında önce teknoloji bağımlılığı ölçeği ve kitap okumaya yönelik tutum ölçeğinin uygulanan örneklem grubu üzerinde kaç faktörlü ve kaç maddelik bir yapıya sahip olduğunu anlayabilmek için ölçekler üzerinde açımlayıcı faktör analizi, doğrulayıcı faktör analizi ve güvenirlik analizleri gerçekleştirilmiştir. Güvenirlik analizleri cronbach alfa iç tutarlılık katsayıları ve madde toplam korelasyon katsayıları incelenerek tamamlanmıştır. Uygulanan sonuçlara göre teknolojik bağımlılık ölçeğinin yoksunluk ve sosyal dışlanmışlık alt boyutları ile 15 maddeden, kitap okumaya yönelik tutum ölçeğinin ise olumlu düşünce, sevgi, yarar alt boyutları ile toplam 25 maddeden oluştuğu görülmüştür. Çalışma grubunun teknoloji kullanımı ve kitap okuma alışkanlıklarına ilişkin betimsel bilgileri sütun grafikler aracılığıyla raporlanmıştır. Ek olarak kitap okuma alışkanlığ üzerinde teknoloji bağımlılığının etkisini tespit edebilmek amacıyla çoklu regresyon analizi gerçekleştirilmiştir. Veriler SPSS 22.0 ve MPlus 8.0 programları aracılığılyla analiz edilmiştir.

\section{Bulgular ve Yorum}

\subsection{Teknoloji Bağımlılığı ile Kitap Okumaya Yönelik Tutum Arasındaki İlişkinin İncelenmesi}

Araştırmada öncelikli olarak lise öğrencilerinin kitap okumaya yönelik tutumları ve teknoloji bağımlılıkları arasındaki korelasyon katsayıları ele alınmıştır. Teknoloji bağımlılığının alt boyutlarını sosyal dışlanmışlık ve yoksunluk oluştururken, kitap okumaya yönelik tutumun alt boyutlarını olumlu düşünce, sevgi ve yarar oluşturmaktadır. Değişkenlere ait korelasyon katsayıları Tablo 1'de yer almaktadır.

Tablo 1. Teknoloji bağımlılığı ile kitap okumaya yönelik tutum arasındaki korelasyon katsayıları

\begin{tabular}{|l|c|c|c|c|c|c|c|}
\hline Değişkenler & $\mathbf{1}$ & $\mathbf{2}$ & $\mathbf{3}$ & $\mathbf{4}$ & $\mathbf{5}$ & $\mathbf{6}$ & $\mathbf{7}$ \\
\hline Olumlu Düşünce (1) & 1 & & & & & & \\
\hline Sevgi (2) &, $303^{* *}$ & 1 & & & & & \\
\hline Yarar (3) &, $619^{* *}$ &, $229^{* *}$ & 1 & & & & \\
\hline Kitap Okuma Toplam (4) &, $839^{* *}$ &, $720^{* *}$ &, $729^{* *}$ & 1 & & & \\
\hline Yoksunluk (5) &,$- 139^{* *}$ &,$- 115^{* *}$ &,$- 263^{* *}$ &,$- 207^{* *}$ & 1 & & \\
\hline Sosyal Dışlanmışlık (6) &,$- 138^{* *}$ &,$- 153^{* *}$ &,- 057 &,$- 163^{* *}$ &, $449^{* *}$ & 1 & \\
\hline Teknoloji Bağımlılı̆̆ı (7) &,$- 159^{* *}$ &,$- 145^{* *}$ &,$- 227^{* *}$ &,$- 221^{* *}$ &, $947^{* *}$ &, $713^{* *}$ & 1 \\
\hline
\end{tabular}

${ }^{*} \mathrm{p}<.05 .{ }^{* *} \mathrm{p}<.01 ; * * * \mathrm{p}$ değeri değişkenler arasındaki ilişkilerin ya da farkların anlaşılmasında kabul edilebilir hata düzeyini göstermektedir. p değerinin .05 'den küçük olması fark ya da ilişkinin anlamlılığının bir belirtisi olarak sayılmaktadır. p değerinin .01'den küçük olması ise bu fark ya da ilişkinin daha az hata ile hesaplandığını ifade etmektedir. 
Tablo 1'de görüldüğü gibi kitap okumaya ait olumlu düşünce boyutu ile yoksunluk ve sosyal dışlanmışlık alt boyutları arasındaki korelasyon katsayıları -.14 iken teknoloji bağımlılığı ile -.16'lık bir korelasyon katsayısı vardır. Kitap okumaya ait sevgi boyutu ile yoksunluk alt boyutu arasındaki korelasyon katsayısı -.12 iken sosyal dışlanmışlık ve teknoloji bağımlılığı toplam puanı arasındaki korelasyon katsayıları -.15'dir. Yarar alt boyutu ile yoksunluk alt boyutu arasındaki korelasyon katsayısı -.26 iken sosyal dışlanmışlıkla aralarında anlamlı bir ilişki görülmemiştir. Kitap Okumaya Yönelik Tutum Ölçeği toplam puanı ise yoksunluk alt boyutuyla -.21 , sosyal dışlanmışlık alt boyutu ile -.16, ve teknoloji bağımlılığı toplam puanıyla -.22'lik bir korelasyon katsayısı vardır. Korelasyon katsayıları teknoloji bağımlılı̆̆ı puanları arttıkça, kitap okumaya yönelik tutum puanlarının azaldığını ifade etmektedir. Örneğin kitap okumaya yönelik olumlu düşünce puanları artış gösterirken, teknoloji bağımlılığının alt ölçeklerinden olan yoksunluk, sosyal dışlanmışlık ve teknoloji bağımlılığı ölçeği toplam puanı düşüş göstermektedir.

Araştırmada teknoloji bağımlılığın kitap okuma üzerindeki etkisini anlayabilmek amacıyla çoklu regresyon analizi uygulanmıştır. Çoklu regresyon analizi bağımlı değişkeni açıklamak için bağımsız değişkenlerin rolünün tespit edilmesine olanak sağlayan bir analiz türüdür (Tabachnick ve Fidell, 2015). Tablo 2'de regresyon analizi sonuçları belirtilmektedir.

Tablo 2. Kitap okumaya yönelik tutumun yordanmasinda teknoloji bağimliliğinin rolüne ilişkin çoklu regresyon analizi sonuçlari

\begin{tabular}{|l|c|c|c|c|c|c|}
\hline Model & Yordayıcı & B & SH & \multicolumn{1}{c|}{ Sig. } & \multicolumn{1}{c|}{$\mathbf{R}^{2}$} \\
\hline \multirow{3}{*}{1} & Sabit & 112.601 & 1.453 & $.00 * *$ & - & \\
& Yoksunluk & -.284 & .056 & $.00 * *$ & -.168 & .049 \\
\cline { 2 - 7 } & Sosyal Dişlanmışlık & -.321 & .122 & $.00 * *$ & -.087 & \\
\hline
\end{tabular}

${ }^{*} \mathrm{p}<.05 ; * * \mathrm{p}<.01$

Tablo 2 analiz edildiğinde teknoloji bağımlılı̆̆ının kitap okumaya ilişkin tutumun \% 5 'lik bir kısmını açıkladığı anlaşılmaktadır. Teknoloji bağımlılığının yoksunluk ve sosyal dışlanmışlık alt boyutlarının katkısı manidardır. Kitap okumaya yönelik tutum üzerinde yoksunluk boyutunun rolü sosyal dışlanmışlığa göre daha yüksektir.

\subsection{Teknoloji Bağımlılığının Cinsiyete Göre Farklılaşma Durumunun İncelenmesi}

Lise öğrencilerinin teknoloji bağımlılığı ölçeğinden aldıkları puanların cinsiyetlerine göre karşılaştırıldığı t-testi sonuçları Tablo 3'de yer almaktadır. Tablo 3 analiz edildiğinde kız öğrencilerin teknoloji bağımlılığı puanları erkek öğrencilerin teknoloji bağımlılığı puanlarına göre anlamlı düzeyde yüksektir $(\mathrm{t}=2,27, \mathrm{p}<.05)$. Erkeklerin puan ortamaları 31,63 iken, kız öğrencilerin puan ortalamaları ise 33,24'dür. Elde edilen bu istatistiksel farkın pratikteki 
karşılığını anlayabilmek amacıyla uygulanan etki büyüklüğü hesaplamasında ise sonuç .0 olarak hesaplanmıştır. Etki büyüklüğünün .01-.06 arasında yer alması küçük düzeyde olduğunun belirtisi olarak kabul edilmektedir (Büyüköztürk, 2018). Araştırma sonucunda ulaşılan etki büyüklüğü değeri ise 0 'a yakındır. Yani kız öğrencilerin puanları ile erkek öğrencilerin puanları arasındaki manidar fark pratik anlamda bir etkiye sahip değildir.

Tablo 3. Teknoloji bağımlılığı ölçeğinin cinsiyete göre T-Testi sonuçları

\begin{tabular}{|l|c|c|c|c|c|c|c|c|}
\hline Değişken & Cinsiyet & N & B & S & sd & T & P & $\boldsymbol{\eta}^{2}$ \\
\hline $\begin{array}{l}\text { Teknoloji } \\
\text { bağımlılı̆̆ }\end{array}$ & Erkek & 470 & 31,63 & 11,01 & \multirow{2}{*}{932} & 2,27 & \multirow{2}{*}{, $02 *$} & .00 \\
\cline { 1 - 9 } & $\mathrm{K} 1 \mathrm{z}$ & 464 & 33,24 & 12,02 & 932 & \\
\hline
\end{tabular}

${ }^{*} \mathrm{p}<.05$

\subsection{Kitap Okumaya Yönelik Tutumun Cinsiyete Göre Farklılaşma Durumunun İncelenmesi}

Öğrencilerin kitap okumaya yönelik tutumlarının cinsiyetlerine göre karşılaştırıldığı t-testi sonuçları Tablo 4'de yer almaktadır. Tablo 4 incelendiğinde kız öğrencilerin kitap okumaya yönelik tutumlarının erkek öğrencilere göre anlamlı olarak daha yüksek olduğu görülmektedir $(\mathrm{t}=6,85, \mathrm{p}<.01)$. Erkek öğrencilerin puan ortalamaları 99,03'iken kız öğrencilerin puan ortalamaları 105,79'dur. Ulaşılan bu istatistiksel farkın pratikteki karşılığını anlayabilmek amacıyla yapılan etki büyüklüğü hesaplamasında ise sonuç .04 olarak ortaya çıkmıştır. .01-.06 arasında olduğu tespit edilen bu katsayı, etki büyüklüğünün küçük olduğunu göstermektedir (Büyüköztürk, 2018). Yani kız öğrencilerin puanları ile erkek öğrencilerin puanları arasındaki manidar fark pratik anlamda küçük bir etkiye sahiptir.

Tablo 4. Kitap okumaya yönelik tutum ölçeğinin cinsiyete göre T-Testi sonuçları

\begin{tabular}{|l|c|c|c|c|c|c|c|c|}
\hline Değişken & Cinsiyet & N & B & S & sd & t & P & $\boldsymbol{\eta}^{2}$ \\
\hline \multirow{2}{*}{ Kitap okuma } & Erkek & 470 & 99,03 & 16,36 & \multirow{2}{*}{932} & 6,85 &, $00 *$ & .04 \\
& $\mathrm{~K} 1 \mathrm{z}$ & 464 & 105,79 & 15,96 & & & & \\
\hline
\end{tabular}

$* \mathrm{p}<.01$

\subsection{Araştırmada Kullanılan Anket Verilerine Göre Elde Edilen Sonuçlar}

\subsection{1. Öğrencilerin Boş Zaman Aktiviteleri}

Öğrenciler, boş zamanlarınızda neler yaparsınız sorusuna \%73 oranında bilgisayar ve internette zaman geçiririm cevabını vermiştir. \%53,5'i kitap, dergi ya da gazete okuduğu ve \%31,3'ü spor yaptığını ifade etmiştir. \%11,1'lik kısım sinema ya da tiyatroya gittiğini ifade ederken, televizyon seyrettiğini söyleyenlerin oranı \%10'dur. Cinsiyete göre verilen cevaplar incelendiğinde ise erkek öğrencilerin bilgisayar/internet ve spor yapma faaliyetleri ile kız 
öğrencilere göre daha çok zaman geçirdikleri anlaşılmaktadır. Kız öğrenciler ise okumaya yönelik faaliyetlere erkek öğrencilere göre daha çok zaman ayırmaktadırlar.

Grafik 1. Boş zaman aktiviteleri

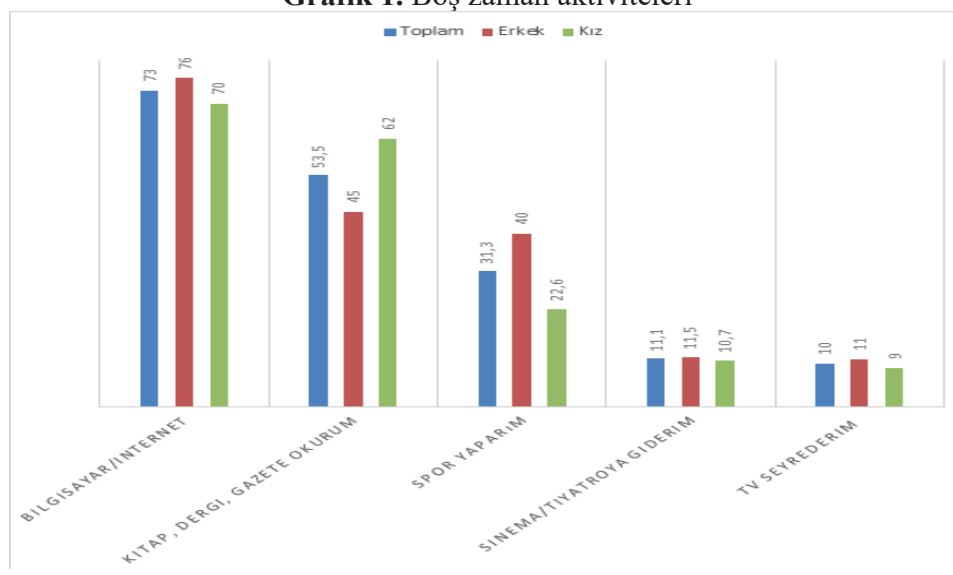

\subsection{2. Öğrencilerin Kullandıkları Teknolojik Aletler}

Öğrenciler hangi teknolojik aletleri kullanıyorsunuz sorusuna dört farklı cevap vermiştir. Grafik 2'de görüldüğü gibi öğrencilerin \%85,7'lik bir kısmı akıllı telefon kullandığını belirtmiştir. \%47,6'sı bilgisayar ve \%28'i tablet kullandığını ifade etmiştir. Bununla birlikte öğrencilerin \%3,6'sı ise e-kitap okuyucu kullandığını ifade etmiştir. Öğrencilerin \%5,6'sı ise hiçbir teknolojik cihaz kullanmadıklarını belirtmiştir. Öğrencilerin cevapları sosyoekonomik koşullara göre ele alındığında ise sosyoekonomik düzey düştükçe öğrencilerin teknolojik cihazlara erişiminin azaldığ 1 anlaşılmaktadır.

Grafik 2. Kullanılan teknolojik cihazlar

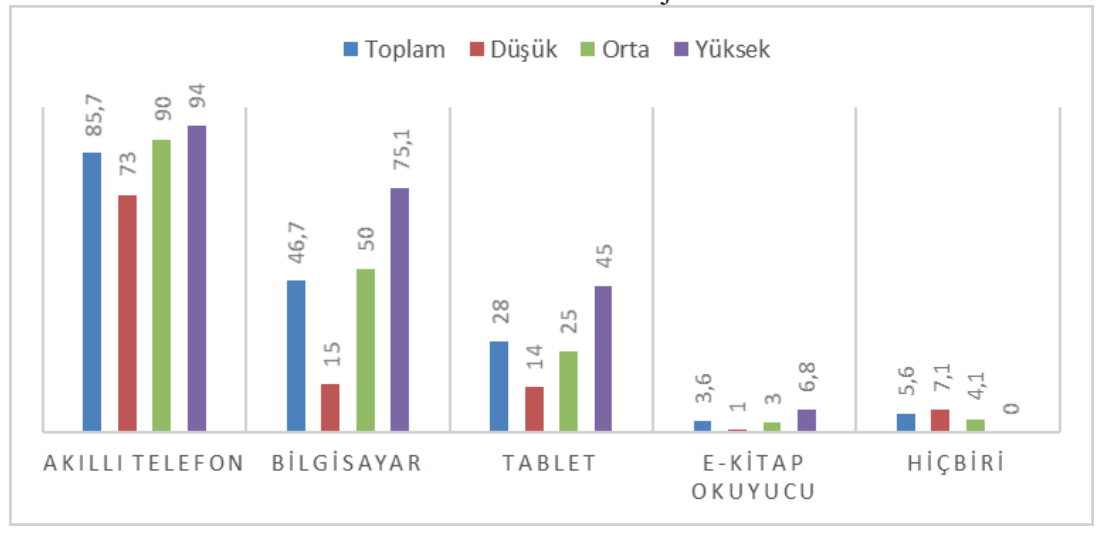




\subsection{3. Öğrencilerin İnternete Erişim İçin Kullandıkları Araçlar}

Öğrenciler internete üç farklı yoldan erişmektedir. Öğrencilerin büyük bir çoğunluğu akıllı telefon üzerinden internete erişirken (\%92,7), $\% 25,1^{\prime} \mathrm{i}$ bilgisayar ve $\% 11,8^{\prime} \mathrm{i}$ ise tablet üzerinden internete eriştiğini ifade etmişlerdir.

\subsection{4. Öğrencilerin Evlerinde İnternet Mevcudiyeti}

Grafik 3 incelendiğinde öğrencilerin \%75'i evlerinde internet olanağına sahipken, \%25'lik kısım ise evlerinde internet bağlantısı olmadığını ifade etmiş̧tir.

Grafik 3. Evde internet durumu

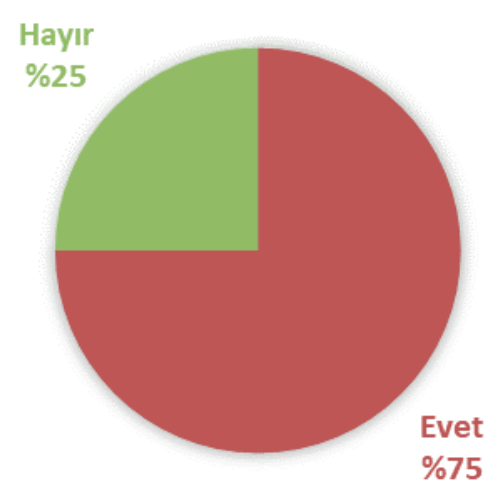

\subsection{5. Öğrencilerin Evlerindeki İnternetin Hızı}

Öğrencilerin evlerindeki internet hızlarına ilişkin bilgiler aşağıda yer almaktadır. Hanesinde 100 megabitten büyük internet hızı olan öğrencilerin oranı \%16'dır. 50-100 megabit arasında internet hızı olanlar \%24, 30-50 megabit arasında internet hızına sahip olanlar \%13, 10-30 megabit hızına sahip olanlar \%28'dir Son olarak 10 megabitten düşük internet hızına sahip olanların oranı ise \%19'dur.

\subsection{6. Öğrencilerin İnterneti Kullanım Amaçları}

Öğrencilerin interneti kullanım amaçları arasında en yüksek üç amaç sırasıyla film-müzik $(\% 71,7)$, bilgiye erişmek $(\% 68,8)$ ve ödev yapmak $(\% 68,7)$ şeklindedir. Bunları $\% 59,6$ ile vakit geçirmek, $\% 56,9$ ile sohbet etmek, $\% 47,3$ ile sosyal ağlar, $\% 36,8$ ile oyun oynamak ve \%21,6 ile kitap okumak takip etmektedir. Öğrencilerin \%0,4’ü ise bu amaçların hiçbirinin kendisine uygun olmadığını ifade etmiştir. Öğrencilerin internet kullanım amaçları cinsiyete göre karşılaştıııldığında ise erkek öğrencilerin kız öğrencilere göre eğlence amaçlı kullanıma daha yatkın oldukları, kız öğrencilerin ise eğitsel amaçlı kullanımlarının erkek öğrencilere göre daha çok olduğu anlaşılmaktadır. 


\subsection{7. Öğrencilerin Kullandıkları Sosyal Medya Platformları}

Öğrencilerin kullandıkları sosyal medya platformları arasında \% 79,7 ile Instagram birinci siradadır. Instagramı \%69,5 ile YouTube, \%29,5 ile Twitter, \%28,8 ile Facebook ve \%24,3 ile TikTok takip etmektedir. Google Plus kullananların oranı \%8,4, Tumblr kullananların oranı $\% 3,4$, Linkedin kullananların oranı \%2,9 ve WhatsApp kullananların oranı \%2,3'dür. Hiçbir sosyal medya platformu kullanmayanların oranı ise $\% 4,2$ 'dir.

\subsection{8. Öğrencilerin Sosyal Medya Kullanım Amaçları}

Grafik 4 incelendiğinde öğrencilerin sosyal medya kullanım amaçlarında en yüksek yüzdeye \%72,6 ile vakit geçirmek sahiptir. Bilgiye erişmek seçeneği \%71,9 ile ikinci sıradadır. Sohbet etmek seçeneği \%67,1 ile üçüncü, oyun oynamak seçeneği ise \%24,9 ile dördüncü sıradadır. Hiçbiri cevabını veren öğrencilerin oranı ise $\% 1,3$ ' dür.

Grafik 4. Sosyal medya kullanım amacı

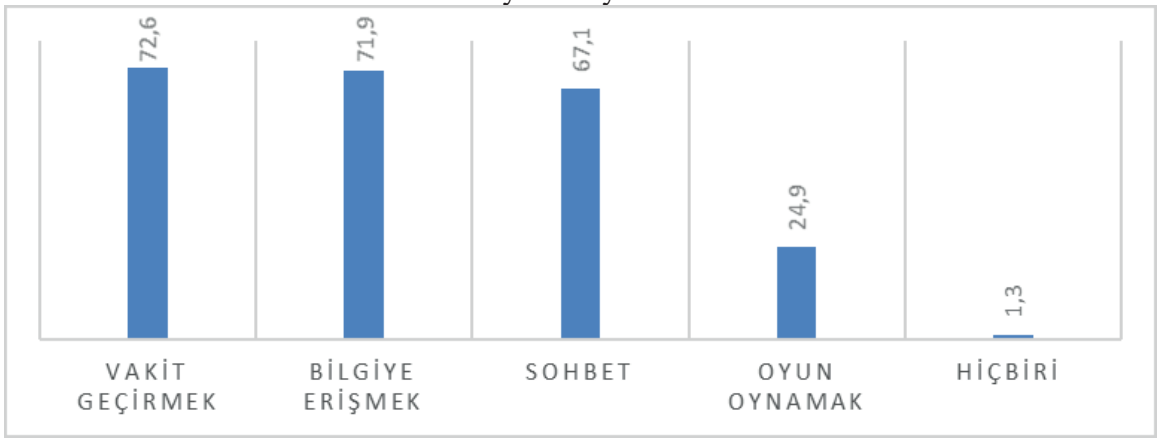

\subsection{9. Öğrencilerin Günlük Ortalama Sosyal Medya Kullanım Süreleri}

Öğrencilerin \%34'ü günde 1-2 saat arasında sosyal medyada vakit harcadıklarını ifade etmişlerdir. İkinci sıra \%31'lik oranla 3-4 saat arasındadır. Sosyal medyada günde1 saatten az zaman geçirenler \%18'dir. \%10'luk dilim günde 5-6 saat arasında sosyal medyada vakit harcarken, 7 saat ve üzerinde zaman geçirenler \%6'dır. Sosyal medyada hiç zaman geçirmediğini belirtenlerin oran 1 ise $\% 1$ 'dir.

\subsubsection{0. Öğrencilerin Kullandıkları Anlık Mesajlaşma Programları}

Öğrencilerin kullandıkları anlık mesajlaşma programları arasında birinci sırada \%92,5 ile WhatsApp bulunmaktadır. \%24,5 ile Snapchat ikinci sıradadır. \%11,7 ile Facebook Messenger üçüncü sıradadır. Facetime \%3,6, Skype \%3, 1, Instagram \%2,4 ve Hangsouts \%1,9 oranlarındadır. Hiçbir anlık mesajlaşma programını kullanmadığını belirten öğrencilerin oranı \%3,6'dır. 


\subsubsection{1. Öğrencilerin Anlık Mesajlaşma Programlarını Günlük Ortalama Kullanım Süreleri}

Anlık mesajlaşma programlarını hiç kullanmayan öğrencilerin oranı \%4 iken, 1 saatten daha az kullananlar \%39'dur. 1-2 saat arasında kullanan öğrencilerin oran $1 \% 36$ iken, 3-4 saat arasında kullananlar \%12 ve 5-6 saat arasında kullananların oranı ise \%6'dır. Öğrencilerin $\% 3$ ’ü anlık mesajlaşma programlarını günlük ortalama 7 saat ve üzerinde kullanmaktadır.

\subsubsection{2. Öğrencilerin Çevrimiçi Oyunlarda Geçirdikleri Günlük Ortalama Süre}

Araştırmada çevrimiçi oyunları oynamadığını belirten öğrencilerin oranı $\% 45^{\prime}$ tir. $\% 28$ 'lik kesim çevrimiçi oyunlara günlük 1 saatten az vakit harcadığını ifade ederken, 1-2 saat arasında vakit harcadıklarını belirtenlerin oranı \% 16 'dır. Çevrimiçi oyunlara günde 3-4 saatini ayıranlar $\% 9$ oranında iken, 5-6 saatini ayıranların ve 7 saat ve üzerinde zaman ayıranların oranı ise \%1'dir. Öğrencilerin çevrimiçi oyunlarda geçirdikleri süre cinsiyete göre karşılaştırıldığında ise erkeklerin kızlara göre çevrimiçi oyunlarda daha çok vakit harcadıkları görülmektedir.

\subsubsection{3. Öğrencilerin Gün İçinde Çevrimiçi Olarak Geçirdikleri Toplam Süre}

Grafik 5 'te öğrencilerin gün içerisinde çevrimiçi olarak geçirdikleri toplam süre dağılımı bulunmaktadır. Öğrencilerin $\% 5^{\prime}$ lik bir kesimi hiç zaman geçirmediğini ifade ederken, $\% 15^{\prime} \mathrm{i}$ bir saatten az vakit harcamaktadır. 1-2 saat ve 3-4 saat arasında vakit geçiren öğrenciler \%27 iken, 5-6 saat arası zaman geçiren $\% 17$ oranındadır. 7 saat ve üzerinde çevrimiçi zaman geçiren öğrencilerin oranı ise $\% 9$ 'dur.

Grafik 5. Öğrencilerin gün içinde çevrimiçi olarak geçirdikleri toplam süre

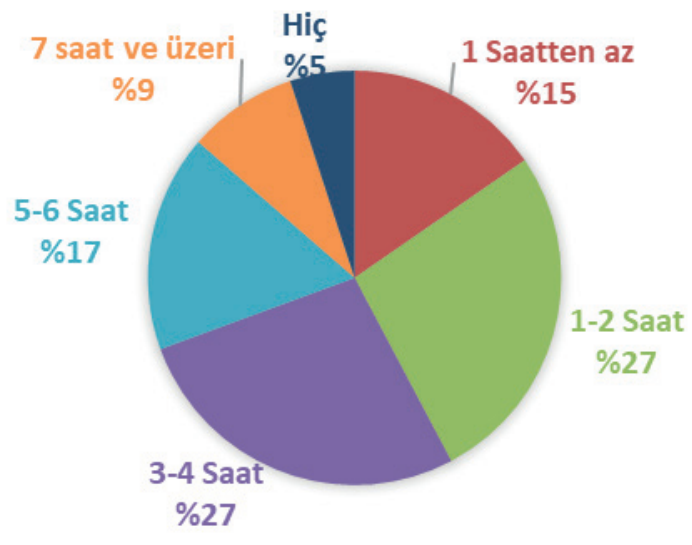




\subsubsection{4. Öğrencilerin Okumaya Ayırdıkları Günlük Ortalama Zaman}

Grafik 6 incelendiğinde öğrencilerin \%11'i kitap okumaya hiç vakit ayırmadıklarını belirtmiştir. Günde 1 saatten az zaman ayıranların oranı \%35, 1-2 saat arasında vakit geçirenlerin oran $1 \% 45,3-4$ saat arasında zaman ayıranların oran $1 \% 7$ ve $5-6$ saat arasında vakit harcayanların oranı \%2'dir. Okumaya ayrılan zaman cinsiyet açısından karşılaştırıldığında kız öğrencilerin erkek öğrencilere göre okumaya daha çok zaman ayırdıkları anlaşılmaktadır.

Grafik 6. Günlük okuma süresi

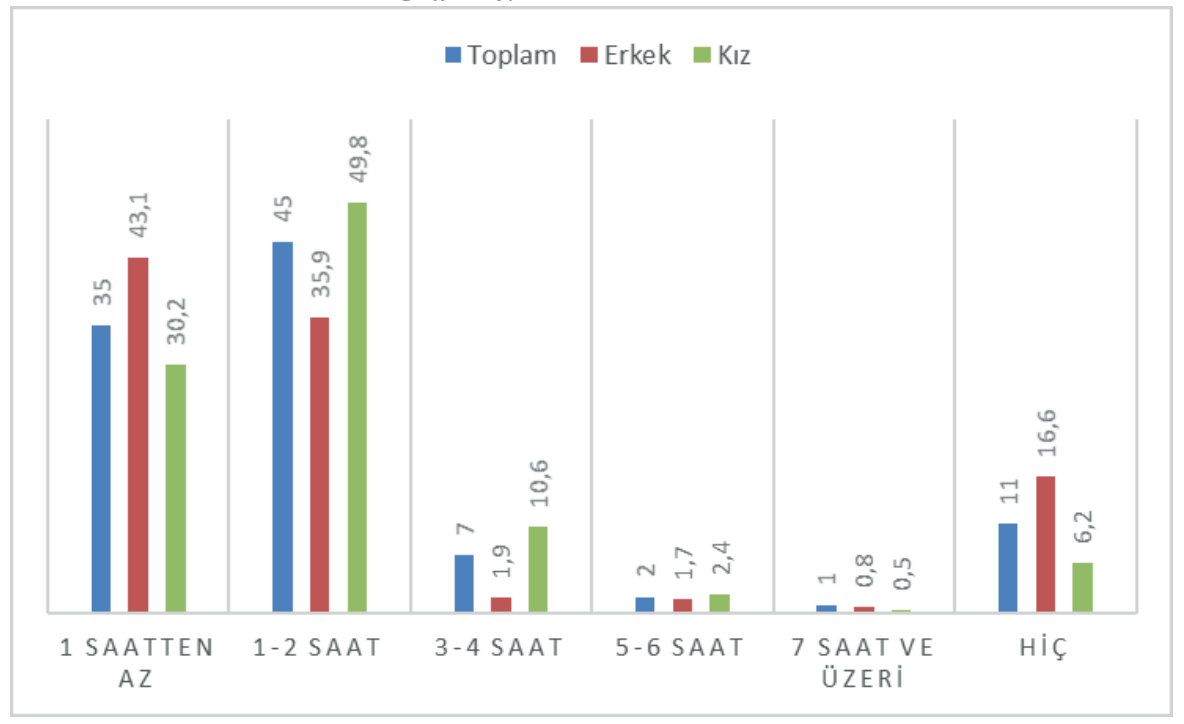

\subsubsection{Son Bir Yılda Okunan Kitap Sayısı}

Son 1 y1l içerisinde 1-5 arasında kitap okuyan katılımcıların oranı \%34, 6-10 arasında kitap okuyanların oranı \%30, 11-20 arasında kitap okuyan öğrencilerin oranı ise \%17'dir. Öğrencilerin \%13'ü 21-50 arasında kitap okuduğunu ifade ederken, 51 ve üzerinde kitap okuyan katılımcılar \%4'lük bir orana sahiptir. Öğrencilerin \%2'si ise hiç kitap okumadıklarını ifade etmişlerdir.

\subsubsection{6. Öğrencilerin Kitap Okuma Ortamları}

Araştırmaya katılan öğrencilerin \%8'i kitap okuma ortamı olarak dijital yayınları tercih ettiklerini belirtmiştir. Basılı yayınları tercih edenlerin oranı ise \%92'dir. Öğrencilerin çoğunluğu okumak için basılı yayınları tercih ettiklerini belirtmiştir.

\subsubsection{Son Bitirilen Kitap Zamanı}

Araştırmaya katılan öğrencilerin \% 73'ü son bir ay içerisinde bitirdikleri bir kitabın olduğunu söylemişlerdir. Son bitirilen kitabın son iki ay içerisinde olduğunu söyleyenlerin oranı ise 
$\% 11$ 'dir. Son bitirilen kitabın zaman aralığı son altı ay olanların oranı $\% 6$, son üç ay olanların oranı $\% 5$, son bir yıl olanların ise $\% 3$ oranında olduğu anlaşılmaktadır. Son olarak; hiç kitap bitirmeyenlerin oranı ise; \%2'dir. Öğrencilerin önemli bir kesimi her ay ortalama 1 kitap bitirdiklerini belirtmiştir.

\subsubsection{8. Öğrencilerin Kütüphaneye Gitme Durumları}

Grafik 7‘de görüldüğü üzere araştırmaya katılan öğrencilerin \%63’ü kütüphaneye gittiklerini ifade etmiştir. Diğer taraftan kütüphaneye gitmediğini söyleyen öğrencilerin oranı ise \%37'dir.

Grafik 7. Kütüphane kullanım durumu

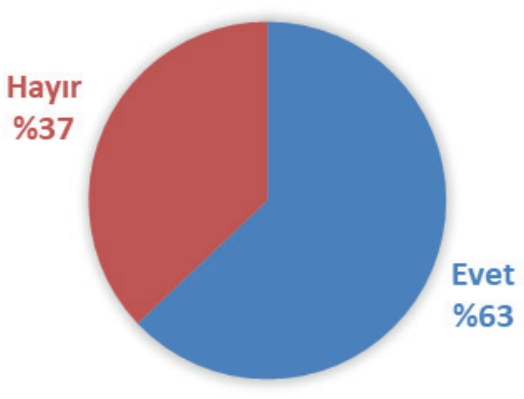

\subsubsection{9. Öğrencilerin Kullandıkları Kütüphane Türü}

Katılımcıların \%69'u okul kütüphanelerini tercih ettiklerini ifade ederken, \%53,7'si ise halk kütüphanelerini kullandıklarını belirtmektedir. $\% 6,5$ 'lik kesim üniversite kütüphanelerini tercih ettiğini belirtirken, $\% 1,2$ çocuk kütüphanesini, \%0,1 ise dershane kütüphanesini kullandıklarını ifade etmiştir.

\subsubsection{0. Öğrencilerin Halk Kütüphanelerine Gitme Sıklıkları}

Katılımcıların \%7'si halk kütüphanelerine haftada bir kez gittiğini ifade ederken, haftada birkaç kez gittiklerini söyleyenlerin oranı ise \%11'dir. Halk kütüphanelerini kullanma sıklığ1, ayda birkaç kez olanlar \%21 'ken yılda birkaç kez olanların oranı \% 15'dir. Halk kütüphanelerini hiç kullanmıyorum diyenlerin oranı ise; \%46'dır.

\subsubsection{1. Öğrencilerin Halk Kütüphanesine Üye Olma Durumları}

Çalışma grubundaki öğrencilerin \%37'si halk kütüphanelerine üye olduğunu ifade ederken, $\% 63$ 'ü ise üye olmadığını belirtmektedir. 


\subsubsection{2. Öğrencilerin Halk Kütüphanesi E-Devlet Üyelik Bilgileri}

Araştırmaya katılan öğrencilerden halk kütüphanesi üyeliklerini E- Devlet üzerinden gerçekleştirebileceklerine dair bilgi sahibi olanların oranını \%21 iken, bilgi sahibi olmayanların oranının $\% 79$ olduğu anlaşılmaktadır.

\subsubsection{3. Öğrencilerin Kütüphane Görevlilerinden Yardım İsteme Durumları}

Katılımcıların verdiği cevaplara göre kütüphane görevlilerinden yardım alanlar \%63 iken, kütüphane görevlilerinden yardım almayanların oranının ise; \%37 olduğu görülmektedir.

\subsubsection{4. Öğrencilerin Okul Kütüphanesine Gitme Sıklıkları}

Araştırmaya katılan öğrencilerin \%11'i okul kütüphanesine yılda birkaç kez gitmektedir. Öğrencilerin \%16'sı okul kütüphanesine ayda birkaç kez gittiğini ifade ederken, \%18'i haftada bir kez gittiğini belirtmiştir. Okul kütüphanesini hiç kullanmıyorum diyenler \%23 iken, haftada birkaç kez giderim diyenlerin oranı ise $\% 32$ 'dir.

\subsubsection{5. Öğrencilerin Okul Kütüphanesine Üye Olma Durumları}

Katılımcıların \%37'si okul kütüphanesine üye olduklarını ifade ederken, \%63'ü okul kütüphanesine üye olmadıklarını belirtmektedir.

\subsubsection{6. Öğrencilerin Kütüphaneleri Kullanım Amaçları}

Grafik 8 incelendiğinde öğrencilerin kütüphaneleri kullanım amaçları içerisinde birinci sıra \%70,3 ile okuma kitabı almak şeklindedir. Bunu sırasıyla \%55,4 ile ders çalışmak, \%39,8 ile ödev yapmak, kitap ve ansiklopedi incelemek takip etmektedir. Bilgisayar ve internet kullanmak için kütüphaneyi kullanan öğrencilerin oranı \%4,8 iken, bu seçeneklerin hiçbiri diyen öğrenciler ise \%10,8 oranındadır.

Grafik 8. Öğrencilerin kütüphaneyi kullanım amaçları

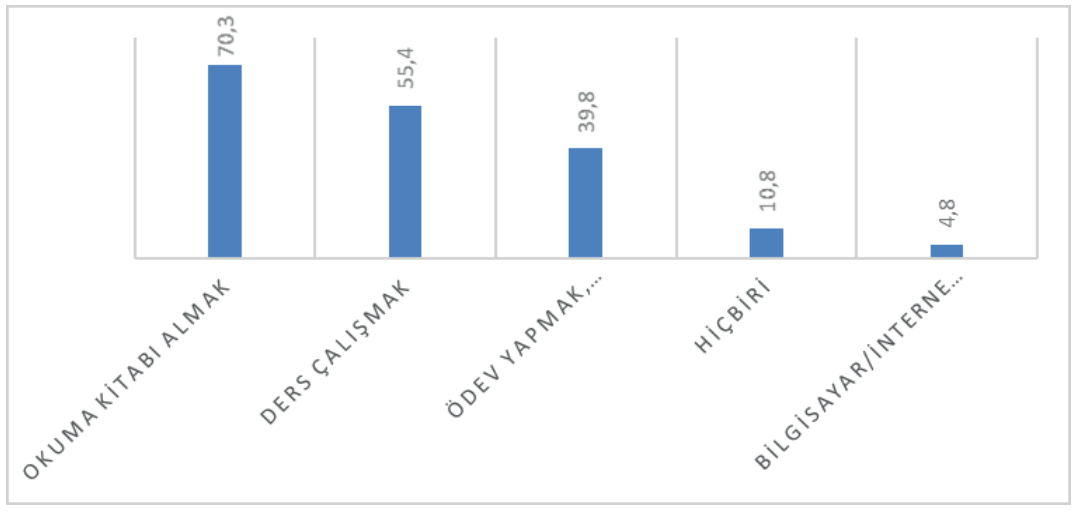




\subsubsection{7. Öğrencilerin Kütüphanelerde Kullandıkları Hizmet Türleri}

Katılımcıların kütüphanede kullandıkları hizmet türleri arasında birinci sırada \%79,3 ile ödünç alma hizmetleri gelmektedir. Bunu \% $\%, 9$ ile fotokopi hizmetleri ve $\% 9,1$ ile elektronik kaynak hizmetleri takip etmektedir. Bu hizmetlerin hiçbirinden faydalanmıyorum diyen katılımcı oranı ise \%16,7 oranındadır.

\subsubsection{8. Öğrencilerin Okul Kütüphanesine Gereksinim Duyma Sebepleri}

Grafik 9 incelendiğinde öğrencilerin okul kütüphanesine gereksinim duyma nedenleri arasında birinci sırada \%65,5 ile kitap ödünç almak bulunmaktadır. Boş zamanları verimli kullanmak \%40,7 ile ikinci sırada, ödevler kapsamında araştırma yapmak ise \%31,2 oranıyla üçüncü sıradadır. Bu seçeneklerin hiçbiri benim için uygun değil diyenler ise \%14'lük bir orana sahiptir.

Grafik 9. Öğrencilerin okul kütüphanesine gereksinim duyma sebepleri

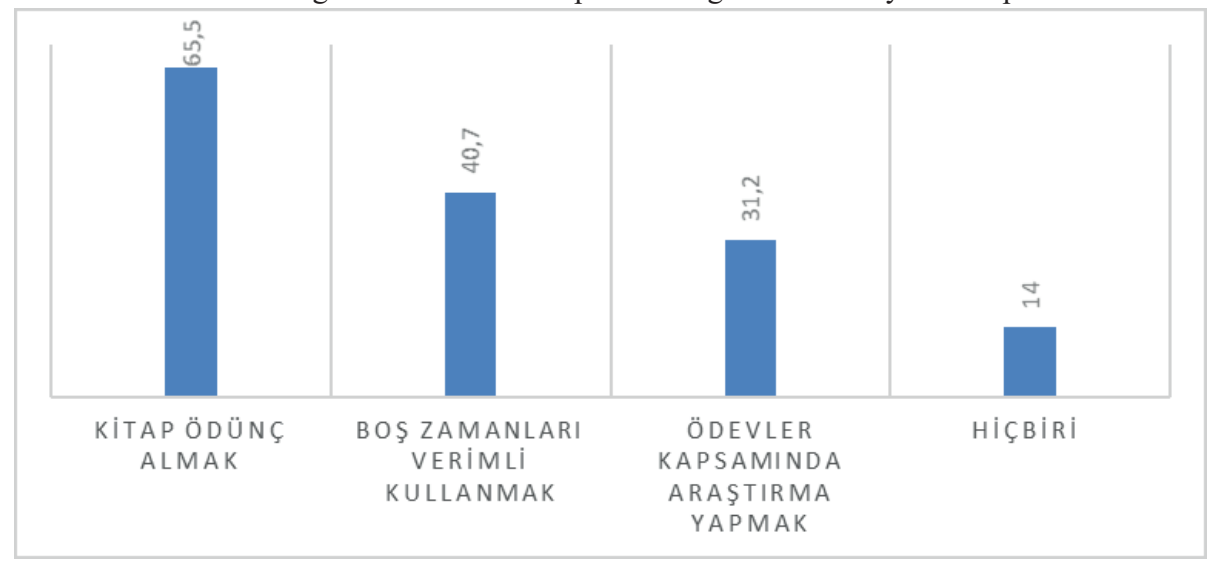

\subsubsection{Okul Kütüphanesini Öğrenciler İçin Önemli Kılan Özellikler}

Katılımcıların \%60,4'ü kütüphanenin ödev yapmak ve ders çalışmak için uygun bir ortam olmasını önemli olarak görmekteyken, \%49,7'lik kesim ise kütüphaneyi merak ettikleri konular için bilgi kaynağı olmasının önemli olduğunu belirtmektedir. \%0,5'lik kesim ise kütüphaneyi kitap alıp okuma amacıyla kullanmalarının önemli olduğunu vurgulamıştır.

\subsubsection{0. Öğrencilerin Okul Kütüphanesinde Tercih Ettikleri Kitap Türleri}

Grafik 10 ele alındığında katılımcıların en yoğun ilgisi \%44,1 ile Türk klasikleri romanlarına yöneliktir. İkinci sırada \%43,7 ile Dünya klasikleri romanları gelirken, üçüncü sırada \%43,1 ile macera romanları gelmektedir. Ders kitapları \%11,2 ve süreli yayınlar \%5,4 ile son sıralarda yer almaktadir. 
Grafik 10. Okul kütüphanesinden tercih edilen kitap türleri

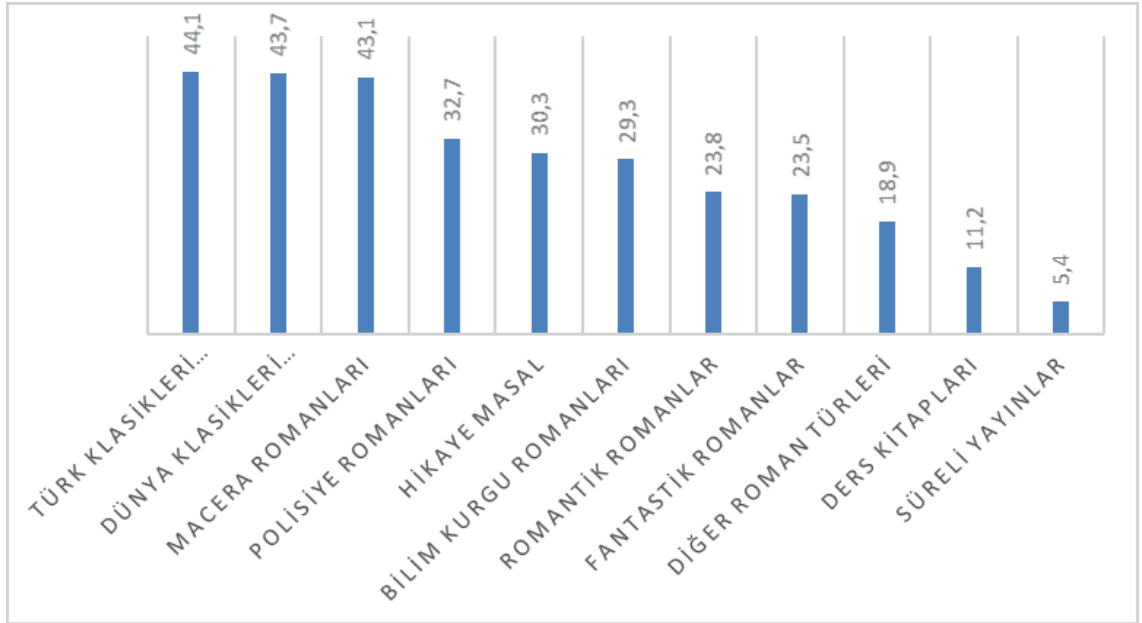

\subsubsection{1. Öğrencilerin Okul Kütüphanesinden Talepleri}

Grafik 11 ele alındığında öğrencilerin okul kütüphanesinden talepleri arasında fotokopi hizmetleri, internet erişimi olan bilgisayarlar ve fiziksel alanın daha geniş olması gelmektedir. Bunların oranı ise \%12'dir. Sessizlik talebinde bulunan kesim \%14 iken, kitap çeşitliliğinin fazla olması talebi \%17 oranındadır. Dijital altyapı ve kaynaklar \%15 oranında iken, elektronik yayın erişimi talebinde bulunanların oranı ise \%18'dir.

Grafik 11. Okul kütüphanesinden talepler

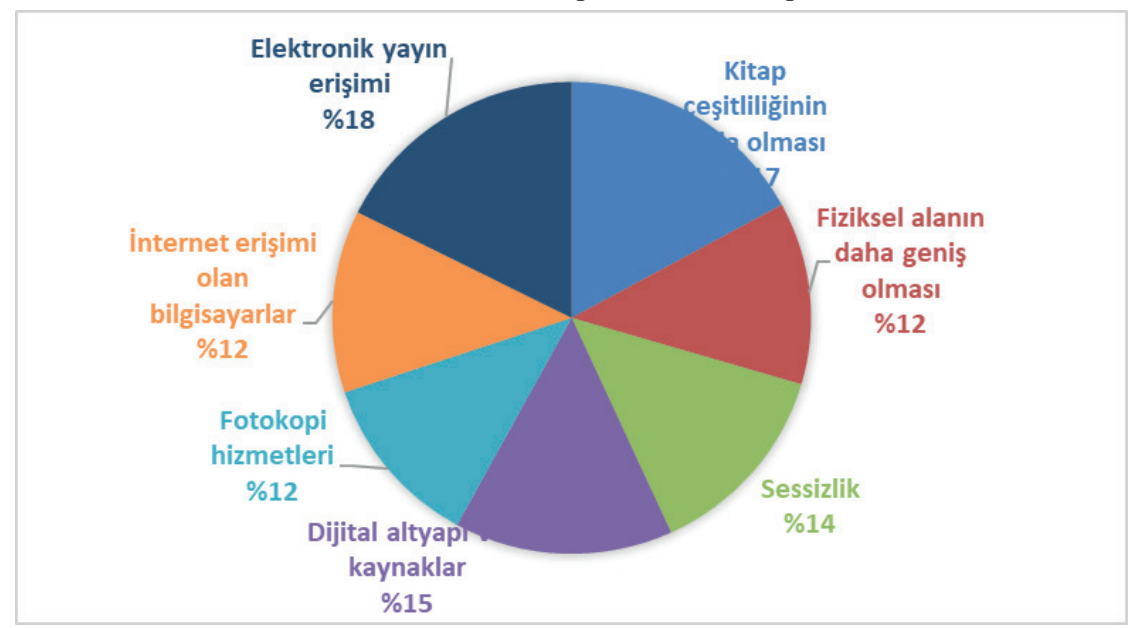




\section{SONUÇ VE ÖNERILLER}

Günümüzde teknoloji aracılığıyla bilgiye erişilebilmektedir. Bu durum teknolojinin olumlu özelliklerinden biridir. Bununla birlikte teknoloji kavramı, teknoloji bağımlılığg ve bilinçsiz internet kullanımı gibi durumları da ortaya çıkarmıştır. Bireyler vakitlerinin çoğunu sosyal medyada, çevrimiçi oyunlarda vb. geçirebilmektedir. Bu durum ise bireylerin okuma alışkanlığına yeteri kadar zaman ayıramamasına yol açabilmektedir. Bireylerin okuma alışkanlığına sahip olamaması bilgi dünyalarını zenginleştirememelerine neden olmaktadır. Araştırma sonucunda ortaöğretim 9. Sınıf öğrencilerinin internet ve sosyal medyayı bilgiye erişmek açısından düşük oranda kullandıkları anlaşılmaktadır. Bu husus, öğrencilere medyayı doğru algılayabilmeleri için verilen 'medya okuryazarlığı' dersini anımsatarak, günümüzde de dijital dünyayı doğru ve etkili kullanabilmeleri için verilen 'dijital okuryazarlık' dersinin önemini göstermektedir. Bütün bu hususlar içeriğinde medya okuryazarlığı ve dijital okuryazarlığı barındıran 'bilgi okuryazarlığı' dersinin ise öğrencilere okutulmasının ne kadar önemli bir durum olduğunu göstermektedir.

Bu çalışmada; ortaöğretim 9. sınıf öğrencilerinin ölçek maddelerine verdikleri cevaplara göre teknoloji bağımlılığı ile kitap okuma alışkanlığı arasındaki ilişki incelenmiştir. Teknoloji bağımlılığı ile kitap okumaya yönelik tutum arasındaki korelasyon katsayıları analiz edildiğinde korelasyon katsayıları teknoloji bağımlılığı puanları arttıkça, kitap okumaya yönelik tutum puanlarının azaldığını göstermektedir. Teknoloji bağımlılığı ile kitap okuma alışkanlığı arasında negatif yönlü bir ilişki vardır. Çalışmada teknoloji bağımlılığının cinsiyete göre farklılaşma durumunu anlayabilmek için uygulanan t-testi ve etki büyüklüğü hesaplamalarına göre teknoloji bağımlılığı cinsiyete göre farklılaşmamaktadır sonucu ortaya çıkmıştır. Araştırmada kitap okumaya yönelik tutumun cinsiyete göre farklılaşma durumu ele alındığında ise uygulanan t-testi ve etki büyüklüğü hesaplamalarına göre kız öğrencilerin kitap okumaya yönelik tutumları erkek öğrencilere göre daha yüksektir sonucu elde edilmiştir. Araştırmada kullanılan anket tekniği vasıtasıyla elde edilen sonuçlara göre kız öğrencilerin erkek öğrencilere kıyasla interneti eğitsel amaçla daha çok kullandıkları, erkek öğrencilerin ise eğlence faktörüne kız öğrencilere kıyasla daha çok zaman ayırdıkları anlaşılmaktadır. Kız öğrenciler internet üzerinden bilgiye erişmek (\%70), ödev yapmak (\%69) ve kitap okumak $(\% 33,2)$ seçeneklerine erkek öğrencilere göre daha yüksek oranlarda cevap vermişlerdir. Bu durum araştırmanın hipotezlerinden biri olan "öğrencilerin internet kullanım amaçları cinsiyete göre farklılaşmaktadır” ifadesinin geçerli olduğunu göstermektedir. Araştırmada çevrimiçi oyun oynama süresinin cinsiyete göre farklılaşmasına yönelik tutumlar ele alındığında ise "öğrencilerin çevrimiçi oyun oynama süreleri cinsiyete göre farklılaşmaktadır" hipotezinin geçerli olduğu görülmektedir. Erkek öğrencilerin \%42,3’ü günde ortalama bir saatin üzerinde çevrimiçi oyunlara zaman ayırırken, bu oran kız öğrencilerde \%17,3’tür.

Ortaöğretim 9. sınıf öğrencilerine yönelik uygulanan anket çalışmasından elde edilen bilgilere göre öğrencilerin $\% 53$ 'ü günde 3 saat ve üzerinde internette vakit geçirmektedir. Günde 3 saat ve üzerinde kitap okuyan öğrencilerin oranı ise \%9'dur. Öğrencilerin bilgisayar 
ve internet ile fazla zaman geçirmeleri ‘boş zamanlarınızda en çok ne yaparsınız' sorusu ile de anlaşılmaktadır. Bu soruya verilen cevapta bilgisayarda/internette vakit geçiririm diyenler $\% 73$ oranındadır. Kitap, dergi, gazete vb. okurum diyenlerin oranı ise $\% 53,5$ 'dir. Öğrencilerin interneti ve sosyal medyayı bilgi edinmek amacıyla kullanmalarının yüksek oranda olduğu anlaşılmaktadır. İnterneti kullanım amaçları arasında film/müzik seçeneği \%71,7 iken, bilgiye erişim seçeneği \%68,8 oranındadır. Sosyal medyada vakit geçirmek seçeneği ise \% 72,6 iken, bilgiye erişim seçeneği \% 71,9'dur. Ancak soruda birden fazla seçeneklerin işaretlenebilmesinden dolayı sohbet, oyun oynamak vb. seçeneklerinde yüksek olmasından dolayı öğrencilerin internet ve sosyal medyayı bilgi edinmek açısından yeterli seviyede kullanamadıkları söylenebilir. Bu nedenle öğrencilere verilecek bilinçli internet kullanımı eğitimlerinin önemi büyüktür.

Yapılan araştırmada öğrencilerin kitap okumaya yönelik görüşleri ele alındığında "günde ortalama ne kadar süre kitap okuyorsunuz" seçeneğine hiç cevabını (\%11) verenlerin düşük oranda olmasının öğrencilerin düzenli kitap okuma alışkanlıklarına sahip olduklarını göstermektedir. Öğrencilerin düzenli kitap okuma alışkanları olmasına rağmen okumaya ayırdıkları günlük sürenin düşük düzeyde olmasının nedeni öğrencilerin teknoloji kullanımına ayırdıkları sürenin fazlalığıyla ilişkilendirilmektedir. Öğrencilerin \%54'ü günde 1 saatin üzerinde kitap okumaktadır. Bu durum son bitirilen kitap zamanından da anlaşılmaktadır. Öğrencilerin \%73'ü en son ne zaman bir kitap bitirdiniz sorusuna son bir ay içerisinde cevabını vermiştir. Son 1 yılda okunan kitap sayıları incelendiğinde öğrencilerin \%34'ü az okuyan okur tipi (1-5 arası kitap), \%47'sinin ise orta düzeyde okuyan okur tipi (6-20 arası kitap) oldukları tespit edilmiştir. Öğrencilerin \%17'sinin ise çok okuyan okur tipi (20 kitap üzeri) oldukları anlaşılmıştır.

Bu çalışmada kütüphane kullanım kültürü ele alındığında öğrencilerin \%37'lik kısmının kütüphanelere gitmediklerini söyledikleri anlaşılmaktadır. Öğrencilerin en çok okul kütüphanelerini (\%69) tercih ettikleri, ikinci olarak ise halk kütüphanelerini $(\% 53,7)$ kullandıkları araştırmada elde edilen sonuçlardandır. Öğrencilerin halk kütüphanelerini düşük oranda kullandıkları görülmektedir. Öğrencilerin \%61'i halk kütüphanelerine hiç gitmem ve y1lda birkaç kez giderim seçeneklerini işaretlemiştir. Bu durum \%63'lük bir oranla halk kütüphanelerine üye olmamalarından ve \%79'luk bir oranla da e-devlet üzerinden halk kütüphanelerine üye olunacağını bilmemelerinden de anlaşılmaktadır. Bundan dolayı öğrencilerin halk kütüphanelerine üyelikleri konusunda okullarda bilgilendirme çalışmalarının yapılması önemlidir ve bu hususta öğretmenlere ve okul idarecilerine önemli görevler düşmektedir. Öğrencilerin \%34'ünün okul kütüphanelerine hiç gitmem ve yılda birkaç kez giderim seçeneklerini işaretlemesi öğrencilerin okul kütüphanelerini kullandıklarının bir göstergesidir. Öğrencilerin kütüphaneleri kullanım amaçları ele alındığında ise ödünç kitap almak ve ders çalışmak seçeneklerinin ön planda olduğu görülmektedir. Öğrencilerin okul kütüphanesinde tercih ettikleri kitap türleri incelendiğinde ise en yüksek oranların Türk klasikleri ve dünya klasikleri olduğu araştırmadan çıkan sonuçlardandır. Araştırmada öğrencilerin okul kütüphanelerinden beklentileri incelendiğinde ise elektronik yayın erişimi (\%18), dijital alt yapı ve kaynaklar (\%15), 
internet erişimi olan bilgisayarlar (\%12) seçeneklerinin yüksek olması zenginleştirilmiş kütüphaneler projesinin geliştirilmesi hususunun ne kadar önemli olduğunu göstermektedir.

Öğrenciler; 'kütüphanede kütüphanecilerden yardım alıyor musunuz' sorusuna \%63 oranında kütüphanecilerden yardım aldıklarını ifade etmiştir. Kütüphaneciler öğrencilere yardım açısından önemlidir ve günümüzde kütüphanecilerin bilgi teknolojisi becerilerine sahip, bilgi okuryazarı bireyler olması öğrencilere verebilecekleri faydalar açısından doğru orantılıdır denilebilir.

Araştırmada, öğrencilerin kütüphane kullanım alışkanlıkları incelendiğinde \%37'lik bir kısmın "kütüphanelere hiç gitmem" ve "yılda birkaç kez giderim" demesi, bu öğrencilerin kütüphanelerin imkânlarından az faydalandıklarını göstermektedir. Bu nedenle Bilgi ve Belge Yönetimi alanında çalışan uzmanların kütüphaneleri klasik kütüphane anlayışından çıkartarak, teknolojik olanakların yoğun olduğu, etkinlik odaklı, bir cazibe merkezine çevirebilmelerinin önemi fark edilen ayrıntılardandır. Öğrencilerin okul kütüphanelerinden beklentileri de bu durumu desteklemektedir.

Hakem Değerlendirmesi: Dış bağımsız.

Çıkar Çatışması: Yazar çıkar çatışması bildirmemiştir.

Finansal Destek: Yazar bu çalışma için finansal destek almadığını beyan etmiştir.

Peer-review: Externally peer-reviewed.

Conflict of Interest: The author has no conflict of interest to declare.

Grant Support: The author declared that this study has received no financial support.

\section{Kaynakça/References}

Aydın, F. (2017). Teknoloji bağımlılı̆̆ının sınıf ortamında yarattığı sorunlara ilişkin öğrenci görüşleri, (Yayımlanmamış yüksek lisans tezi). Ankara Üniversitesi Eğitim Bilimleri Enstitüsü, Ankara.

Aydoğdu, H. (2020). Okuma alışkanlığı ve okul kütüphanelerinin bireysel gelişime etkisi üzerine bir değerlendirme. Milli Ĕ̈itim Dergisi, 49(225), 201-226.

Bamberger, R. (1990). Okuma alışkanlığını gelişstirme. Bengü Çapar (çev.). Ankara: Kütüphaneler Genel Müdürlüğü.

Baldini, M. (2000). İletişim tarihi. İstanbul: Avcıl Yayıncılık.

Cengiz, E. (2019). Halk kütüphanelerinde derme geliştirme politikalart: Türkiye için bir değerlendirme. İstanbul: Hiperlink Yayınevi.

Büyüköztürk, Ș. (2018). Sosyal bilimler için veri analizi el kitabı: İstatistik, araştırma deseni, SPSS uygulamaları ve yorum. Ankara: Pegem Akademi.

Büyüköztürk, Ş., Çakmak, E., Akgün, Ö., Karadeniz, Ş. ve Demirel, F. (2017). Bilimsel araştırma yöntemleri. Ankara: Pegem Akademi. 
Çetintaş, B. (2018). Toplumsal iletişim bağlamında kütüphaneler: kavramsal bir değerlendirme. Mediterranean Journal of Humanities, 8(2), 265-275.

Davarcı, N. (2013). İlköğretim 8. sınıf öğrencilerinin kitap okuma alışkanlı̆̆ ile bilgisayar internet kullanımı arasındaki ilişkinin değerlendirilmesi, (Yayınlanmamış yüksek lisans tezi). Çukurova Üniversitesi Sosyal Bilimler Enstitüsü, Adana.

Durualp, E., Durualp, E. ve Çiçekoğlu, P. (2013). Sekizinci sınıf öğrencilerinin kitap okumaya yönelik tutumlarının internet ve kitap okuma alışkanlıkları açısından incelenmesi. Uluslararası Türkçe Edebiyat Kültür Eğitim Dergisi, 2(1), 115-132.

Fatiloro, F., Adesola, A., Hameed, A. Ve Adewumi, M. (2017). A survey on the reading habits among colleges of education students in the information age. Journal of Education and Practice, 8(8), 106-110.

Gömleksiz, M. (2004). Kitap okuma alışkanlığına ilişkin bir tutum ölçeğinin geçerlik ve güvenirliği. Fırat Üniversitesi Sosyal Bilimler Dergisi, 14(2), 185-195.

Güçlü, G. (2015). Yaşam boyu öğrenme argümanı olarak teknoloji bağımlılı̆̆l ve yaşama yansımaları, (Yayınlanmamış yüksek lisans tezi). Cumhuriyet Üniversitesi Eğitim Bilimleri Enstitüsü, Sivas.

Işık, Ö. (2010). Elektronik kitap olgusu ve Türkiye'de durum, (Yayınlanmamış yüksek lisans tezi). Ankara Üniversitesi Sosyal Bilimler Enstitüsü, Ankara.

Konan, N. (2013). İlköğretim okulu yöneticilerinin okuma alışkanlıkları. Kuram ve Uygulamada Eğitim Yönetimi, 19(1), 31-59.

Kuzucuoğlu, H., Şeşen, Y. (2020). Bilgi merkezleri: Sağlık ve afet bilgi yönetimi. İstanbul: Hiperlink Yayınevi. Küçükkalkan, Y. ve Öztürk, S. (2018). İletişim çağında dijital kültür. Konya: Eğitim Yayınevi.

Mantıŏ̆lu, İ. (2017). Anlayarak hızlı okuma ve öğrenme teknikleri. İstanbul: Salon Yayınları.

Odabaş, H., Odabaş, Y. ve Binici, K. (2019). Dijital bilgi kaynakları ve ortamlarının üniversite öğrencilerinin okuma davranışlarına etkileri. Milli Eğitim, 49(227), 89-116.

Önal, İ. ve Alaca, E. (2015). Okul kütüphanesi kullanımında öğretmenlerin rolü ve sorumlulukları. Bilgi Dünyası, 16(1), 105-126.

Rosli, A., Razali, F., Zamil, A., Noor, M. ve Baharuddin, F. (2017). The determination of reading habits among students: A concept. International Journal of Academic Research in Business and Social Sciences, 7(12), 791-798.

Rubin, R. (2017). Foundations of library and information science. American Library Assocation Press.

Sarı, E. (2016). Hızlı okuma. Antalya: Net Medya Yayıncılık.

Sivrikaya, N. (2009). Internet ve elektronik yayıncılı̆̆ın eğitim üzerindeki etkisinin güzel sanatlar fakültesi ögrencileri üzerinde incelenmesi (Yayımlanmamış yüksek lisans tezi). Haliç Üniversitesi Fen Bilimleri Enstitüsü, İstanbul.

Şahin, A. (2010). Türkçe öğretmeni adaylarının kütüphaneleri kullanma durumları. Turkish Studies, 5(4), 1448- 1471 .

Tabachnick, B. ve Fidell, L. (2015). Çok değişkenli istatistiklerin kullanımı. Ankara: Nobel Akademik Yayıncılık.

Ungan, S. (2008). Okuma alışkanlığımızın kültürel altyapısı. Gaziantep Üniversitesi Sosyal Bilimler Dergisi, $7(1), 218-228$.

Y1lmaz, B., Köse, E. ve Korkut, Ş. (2009). Hacettepe üniversitesi ve Bilkent üniversitesi öğrencilerinin okuma alışkanlıkları üzerine bir araştırma. Türk Kütüphaneciliği, 23(1), 22-51.

Y1lmaz, E. (2015). Eğitimde okul kütüphaneleri: Türkiye’de durum. Milli Eğitim Dergisi, (208), 259-286. 
